\title{
Anatomical eponyms - unloved names in medical terminology
}

\author{
F. Burdan ${ }^{1}{ }^{2}$, W. Dworzański ${ }^{1}$, M. Cendrowska-Pinkosz¹ , M. Burdan¹, A. Dworzańska² \\ ${ }^{1}$ Human Anatomy Department, Medical University of Lublin, Poland \\ 2St. John Cancer Centre, Lublin, Poland
}

[Received: 29 July 2015; Accepted: 21 December 2015]

\begin{abstract}
Uniform international terminology is a fundamental issue of medicine. Names of various organs or structures have developed since early human history. The first proper anatomical books were written by Hippocrates, Aristotle and Galen. For this reason the modern terms originated from Latin or Greek. In a modern time the terminology was improved in particular by Vasalius, Fabricius and Harvey. Presently each known structure has internationally approved term that is explained in anatomical or histological terminology. However, some elements received eponyms, terms that incorporate the surname of the people that usually describe them for the first time or studied them (e.g., circle of Willis, follicle of Graff, fossa of Sylvious, foramen of Monro, Adamkiewicz artery). Literature and historical hero also influenced medical vocabulary (e.g. Achilles tendon and Atlas). According to various scientists, all the eponyms bring colour to medicine, embed medical traditions and culture to our history but lack accuracy, lead of confusion, and hamper scientific discussion. The current article presents a wide list of the anatomical eponyms with their proper anatomical term or description according to international anatomical terminology. However, since different eponyms are used in various countries, the list could be expanded. (Folia Morphol 2016; 75, 4: 413-438)
\end{abstract}

Key words: eponyms, anatomical terminology, anatomical term

Uniform international terminology is a fundamental issue of medicine. It is especially important for anatomical and histological vocabularies, since they form a base for the clinical terminology. Names of various organs or structures have developed since early human history. However, first proper anatomical books were written by Hippocrates (460-377 B.C.E.) and later by the doyen of anatomist - Aristotle (384-322 B.C.E.) and Galen (130-201 C.E.). For this reason the modern terms originated from Latin or Greek. In a modern time the terminology was improved in particular by Andreas Vasalius (1514-1564), Hieronymus Fabricius (1537-1619) and William Harvey (1578-1657). Presently each known structure has internationally approved term that is explained in anatomical or histological terminology $[1,10,12-14,22,23,29]$.

However, some elements received eponyms, terms that incorporate the surname of the people that usually describe them for the first time. The best and the most popular examples are circle of Willis, follicle of Graff, fossa of Sylvious or foramen of Monro named after Thomas Willis (1622-1675), Regnier de Graff (1641-1673), Franciscus de le Boë Sylvius (1614-1687) and Alexander Monro (1697-1767), respectively [19]. Since some scientists studied various structures, their names are used for many times. 
Marceli Malpighi (1628-1694) was the first who described blood capillaries (Malpighi vessels), but he also studied anatomy and histology of the kidney (Malpighi glomeruli), spleen (Malpighi noduli), as well as the skin (Malpighi stratum). In medical history there are lots of anatomical families that gave the name for various structures. After Johann Friedrich Meckel the Elder (1724-1774) there is a Meckel's space (dura mater cavity that cover trigeminal ganglion), ganglion (sphenopalatine ganglion) and ligament (portion of the anterior ligament of malleus). His grandson Johann Friedrich Meckel the Younger (1781-1833) was also a famous anatomist and embryologist and his name is even more popular since is used for the ileal diverticulum and cartilaginous bar from which the mandible is formed. The elder Meckel's son, Philipp Friedrich Theodor Meckel (1756-1803) and another grandson, August Albrecht Meckel (1790-1829) were also anatomists but they were not connected to the medical terminology $[4,15,30,32]$.

Since most of experiments were conducted in various medical centres, lots of different names were given for the same structure, e.g., thoracic duct is known as Aseli or Pecquet duct due to the Gasparo Aseli from Cremona (1581-1626) and Jean Pecquet from Montpellier (1622-1674). The influence of local geography is even much stronger in the clinical terminology just to point eponyms for the sideropoenic dysphagia known as Plummer-Vinson (US, Australia, East-South Europe), Paterson-Kelly's (UK) and Waldenstrom-Kjellberg (Scandinavia) syndrome [15, 30].

The above mentioned rule of the author or pioneer principle has not been always kept in the nomenclature. Francois Poupart - a XVII century French surgeon, was not the first who studied the inguinal ligament but it is known as a Poupart ligament, since he described its relevance to hernial repair in Chirurgie complète (Paris, 1695). On the other hand, Alexander Achillini (1463-1512) was the first who found that the bile duct terminates in the duodenum on the major duodenal papilla that is referred after Abraham Vater (1684-1751) as a papilla of Vater [4]. Similar problem is with a Luschka's duct - named after Hubert von Luschka (1820-1875) [5].

In other cases, literature and historical hero influenced medical vocabulary, just to remain the calcaneal tendon and first cervical vertebra known as Achilles tendon and Atlas, respectively.

Some of the anatomical eponyms were taken to clinical practice, e.g. a maxillary sinusitis for older doctor is still known as highmoritis, secondary to the name of Highmore's antrum used for the sinus. It is worth to mention that the larges paranasal sinus was well known to anatomists before Nataniel Highmore (1613-1687), since it had been illustrated by Leonardo da Vinci (1452-1519) and noticed by Giulio Casserio (1561-1616) [4, 15, 30, 32].

Most of the eponyms are very popular and commonly used especially by clinicians. Some of them probably will never be completely replaced by the proper medical term, e.g., Down's syndrome (John Langdon Haydon Down [1828-1896]), Fallot's tetralogy (Étienne-Louis Arthur Fallot [1850-1911]) or Addison's disease (Thomas Addison [1795-1860]). However, all of eponyms have been officially excluded from the anatomical and clinical nomenclature. As it was pointed by Whitworth [30] they " (...) bring colour to medicine, (...) embed medical traditions and culture to our history". However, we also agree with Woywodt and Matteson [32] that "eponyms lack accuracy, lead of confusion, and hamper scientific discussion in a globalised world".

Unlike early modern anatomical terminology established in Basel (1895), Jena (1935) and Paris (1955), the newest version, prepared under Federative Committee on Anatomical Terminology (FCAT) and the 56 Member Associations on the International Federation of the Associations of Anatomists (IFAA), completely withdrawn eponyms from the morphological vocabularies [12]. Ian Whitmore, the Chairman of FCAT, in the preface to the last edition of Terminologia Anatomica (1998) indicates that present version "try to avoid unnecessary change and has adopted many alternatives in common usage in order to encompass the variable way in which the terminology is used in different countries".

It is worth to motioned, the "war" against eponyms starts after the Second World War, when the general publicity inquired about unethical medical practice of Nazi doctors in particular Hans Reiter (1879-1946), who established reactive arthritis (Reither's syndrome), and Friedrich Wegener (1907-1990), who gave the name for the well-known granulomatosis lesion [6]. However, there are also two anatomical eponyms that are directly connected with Nazi and eugenics. Eduard Pernkopf (1888-1955) the author of the famous Pernkopf Atlas of Human Anatomy was a dean of the Medical Faculty at the University of Vienna, as well as an active member of the brown shirt (Sturmabeliung) and the Nazi party. He was responsible for purging 153 Jewish scientists (including three Nobel laureates) from the school but his main crime was the conducting researches on people executed by Gestapo. A warm Nazi sympathizer and 
a strong eugenics supporter was also a Swiss cardiologist Wilhelm His Jr. (1863-1934) — a long time lecturer and finally a Rector of Berlin University. After his fundamental anatomical work dedicated to the conducting cardiac system, the atrioventricular bundle is called around the World as a bundle of His $[6,25]$.

Although the eponyms are officially contraindicated in medical terminology, they are still placed in anatomical and other medical books. They are seen during various medical exams on both preclinical and clinical levels. This is the consequence of their popularity (e.g., Vater papilla, His bundle) or usefulness - they are usually much shorter that the official terms. Probably many physicians will not immediately recognize 'the congenital cyanotic heart disease secondary to the ventricular septal defect, pulmonary stenosis, right ventricular hypertrophy and aortic dextraposition' as a Fallot's tetralogy [9, 26, 28]. Moreover, none of us will be happy to use the entire name in daily practice. However, a large number of eponyms were already forgotten. The presented Table 1 allows checking the seldom or most popular anatomical ones. Nevertheless, the best databank is found in Terminologia Anatomica [12] as well as on various websites (e.g. www.whonamedit. com, www.mondofacto.com, www.medilexicon.com, www.thefreedictionary.com) that permits to check most of surnames used in the anatomical and clinical terminology - that were used to complete our list (Table 1).

\section{Acknowledgements}

The paper is written in memory to our great and unforgettable anatomical teachers Professor Zbigniew Wójtowicz, MD, PhD (1941-2010) and Professor Zygmunt Urbanowicz, MD, PhD (1931-2011).

Table 1. Eponyms and their proper anatomical names/descriptions according to international anatomical terminology. Proper anatomical terms are written in normal letters while descriptions are presented with italic fonts. Structures explained in Terminologia Anatomica - International anatomical terminology by FCAT [12] are written in italic fonts

\begin{tabular}{|c|c|c|}
\hline Eponyms & Proper anatomical term/description & Ref. \\
\hline Abernethy fascia & lliac fascia & 12 \\
\hline Achilles bursa & Bursa of calcaneal tendon & 12 \\
\hline Achilles tendon & Calcaneal tendon & 12 \\
\hline Adam apple & Laryngeal prominence & 12 \\
\hline Adamkiewicz artery & Anterior radicular artery & 12 \\
\hline Addison plane & Transpyloric plane & 12 \\
\hline Albarran gland & Submucosal glands of branching tubules in the subcervical region of prostate gland & 12 \\
\hline Alcock canal & Pudendal canal & 12 \\
\hline Alderman nerve & Auricular branch of vagus nerve & 12 \\
\hline Ammon horn & Hippocampus & 12 \\
\hline Amussat valve & Spiral fold of cystic duct & 4 \\
\hline Amussat valvula & Posterior urethral valves & 4 \\
\hline Andernach bones & $\begin{array}{l}\text { Sutural bones: small irregular bones found along the sutures of cranium, particularly } \\
\text { related to the parietal bone }\end{array}$ & 11 \\
\hline Andersch ganglion & Inferior ganglion, glossopharyngeal nerve & 12 \\
\hline Andersch nerve & Tympanic nerve & 12 \\
\hline Arantius bodies/nodules & Nodules of semilunar cusps & 12 \\
\hline Arantius duct & Ductus venosus & 20 \\
\hline Arantius ligament & Ligamentum venosum & 12 \\
\hline Arantius ventricle & Lower part of rhomboid fossa & 3 \\
\hline Arlt sinus & Inconstant depression on the lower portion of internal surface of lacrimal sac & 3 \\
\hline Arnold bundle & Temporopontine tract & 4 \\
\hline Arnold canal & Hiatus for lesser petrosal canal & 4 \\
\hline Arnold ganglion & Otic ganglion & 12 \\
\hline
\end{tabular}




\begin{tabular}{|c|c|c|}
\hline Arnold nerve & $\begin{array}{l}\text { Trigeminal ganglion; Tentorial nerve; Auricular branch of vagus nerve; Greater occipital } \\
\text { nerve; Lesser petrosal nerve }\end{array}$ & 12 \\
\hline Arnold tract & Frontopontine fibres; Temporopontine tract & 12 \\
\hline Aschoff isthmus & Angular incisive & 7 \\
\hline Aschoff-Tawara node & Atrioventricular node & 12 \\
\hline Aselli canal/duct & Thoracic duct & 16 \\
\hline Auerbach ganglia & Ganglia of myenteric plexus & 4 \\
\hline Auerbach plexus & Myenteric plexus & 12 \\
\hline Baillarger external band stripe & Stria of internal granular layer & 12 \\
\hline Baillarger internal band stripe & Stria of internal pyramidal layer & 12 \\
\hline Ball stripe & Anal valves & 7 \\
\hline Bartholin anus & Superior opening of cerebral aqueduct & 11 \\
\hline Bartholin duct & Major sublingual duct & 12 \\
\hline Bartholin gland & Greater vestibular gland & 12 \\
\hline Baudelocque diameter & External conjugate & 12 \\
\hline Bauhin gland & Anterior lingual gland & 11 \\
\hline Bauhin valve & lleocaecal valve, Ileal orifice & 12 \\
\hline Bechterew nucleus & Superior vestibular nucleus & 12 \\
\hline Bechterew tractus & Spinoolivary tract & 16 \\
\hline Béclard anastomosis & Anastomosis between the right and the left end-branch of deep lingual artery & 21 \\
\hline Béclard triangle & $\begin{array}{l}\text { Area bounded by the posterior border of hypoglossus muscle, the posterior belly } \\
\text { of digastric and the greater horn of hyoid bone }\end{array}$ & 21 \\
\hline Bell nerve & Long thoracic nerve & 12 \\
\hline Bellini ducts & $\begin{array}{l}\text { Papillary ductus: largest straight excretory ducts in the kidney medulla and the papillae } \\
\text { of which openings form the area cribrosa that open into a minor calyx }\end{array}$ & 11 \\
\hline Bellini ligament & $\begin{array}{l}\text { Fasciculus from the ischiofemoral portion of greater articular fibrous capsule of hip that } \\
\text { extends to the greater trochanter }\end{array}$ & 20 \\
\hline Béraud valve/fold & Fold in the interior of lacrimal sac at its junction with the lacrimal duct & 11 \\
\hline Berger space & Space between the patellar fossa of vitreous and the lens & 20 \\
\hline Bergmann cords/striae & Medullary striae of fourth ventricle & 20 \\
\hline Bergmann fibres & Filamentous glia fibres traversing the cerebellar cortex perpendicular to the surface & 18 \\
\hline Bernard canal/duct & Accessory pancreatic duct & 20 \\
\hline Berry ligament & Suspensory ligament of thyroid gland & 12 \\
\hline Bertin bone & Sphenoidal concha & 12 \\
\hline Bertin columns & Renal columns & 12 \\
\hline Bertin ligament & lliofemoral ligament & 12 \\
\hline Betz cells & Internal pyramidal layer the motor area of precentral gyrus of cerebral cortex & 12 \\
\hline Bezold ganglion & Aggregation of nerve cells in the interatrial septum & 26 \\
\hline Bichat canal & Quadrigeminal cistern of subarachnoid space & 11 \\
\hline Bichat fat pad/protuberance & Buccal fat pad & 12 \\
\hline Bichat fissure & $\begin{array}{l}\text { Circular fissure corresponding to the medial margin of cerebral (pallial) mantle, marking } \\
\text { the hilus of cerebral hemisphere, consisting of callosomarginal fissure and choroidal } \\
\text { fissure along the hippocampus }\end{array}$ & 20 \\
\hline Bichat fossa & Pterygopalatine fossa & 11 \\
\hline Bichat ligament & Lower fasciculus of posterior sacroiliac ligament & 11 \\
\hline Bichat membrane/tunic & Tunica intima of blood vessels & 11 \\
\hline Bickel ring & Pharyngeal lymphatic ring & 11 \\
\hline Bigelow septum & Calcar femorale & 20 \\
\hline Bigelow ligament & lliofemoral ligament & 12 \\
\hline
\end{tabular}




\begin{tabular}{|c|c|c|}
\hline Blandin gland & Lingual glands & 12 \\
\hline Blasius duct & Parotid duct & 20 \\
\hline Blumenbach clivus & Clivus & 12 \\
\hline Bochdalek flower basket & $\begin{array}{l}\text { Part of choroid plexus of fourth ventricle protruding through the foramen of Luschka and } \\
\text { resting on the dorsal surface of glossopharyngeal nerve }\end{array}$ & 11 \\
\hline Bochdalek triangle & Lumbocostal triangle & 12 \\
\hline Bogros membrane & Membrane of episcleral space & 21 \\
\hline Bogros space & Retroinguinal spaces & 12 \\
\hline Bonnet capsule & Fascial sheath of eyeball & 4 \\
\hline Botallo duct & Ductus arteriosus & 12 \\
\hline Botallo foramen & Foramen ovale of the heart & 12 \\
\hline Botallo ligament & Ligamentum arteriosum & 1 \\
\hline Botallo node & Lymphatic node of ligamentum arteriosum & 12 \\
\hline Böttcher canal & Utriculosaccular duct & 11 \\
\hline Böttcher ganglion & Ganglion of cochlear nerve & 11 \\
\hline Böttcher sac & Endolymphatic sac & 11 \\
\hline Böttcher space & Endolymphatic space & 11 \\
\hline Bourgery ligament & Oblique popliteal ligament & 20 \\
\hline Bowman capsule & Glomerular capsule & 4 \\
\hline Bowman glands & Olfactory glands & 12 \\
\hline Bowman membrane & Anterior limiting lamina of cornea & 12 \\
\hline Bowman muscle & Ciliary muscle & 4 \\
\hline Bowman space & Space between the visceral and parietal layers of capsule of renal corpuscle & 4 \\
\hline Boxer muscle & Serratus anterior muscle & 12 \\
\hline Boyden sphincter & $\begin{array}{l}\text { Inferior sphincter of hepatopancreatic ampulla (sphincter of common bile } \\
\text { duct immediately proximal to the hepatopancreatic ampulla) }\end{array}$ & 12 \\
\hline Boyer bursa & Retrohyoid bursa & 12 \\
\hline Breschet bones & $\begin{array}{l}\text { Suprasternal bones: one of small ossicles occasionally found in the ligaments } \\
\text { of sternoclavicular articulation }\end{array}$ & 11 \\
\hline Breschet canals & Diploic canals & 11 \\
\hline Breschet hiatus & Helicotrema & 11 \\
\hline Breschet sinus & Sphenoparietal sinus & 11 \\
\hline Breschet veins & Diploic veins & 11 \\
\hline Broca angle $1 / 2$ & $\begin{array}{l}\text { 1. Angle formed at the basion of lines drawn from the nasion and the alveolar point } \\
\text { 2. Angle formed by the intersection at the biauricular axis of lines drawn from the } \\
\text { supraorbital point and the alveolar point }\end{array}$ & 4 \\
\hline Broca area & Subcallosal area & 4 \\
\hline Broca centre/field & $\begin{array}{l}\text { Posterior part of inferior frontal gyrus of left or dominant hemisphere, corresponding } \\
\text { approximately to Brodmann area } 44\end{array}$ & 4 \\
\hline Broca convolution & Inferior frontal gyrus & 7 \\
\hline Broca diagonal band & $\begin{array}{l}\text { Diagonal band; The fibre bundle descending in the precommissural septum toward the } \\
\text { base of forebrain, immediately rostral to the terminal lamina }\end{array}$ & 12 \\
\hline Broca fissure & Fissure surrounding Broca convolution & 11 \\
\hline Broca gyrus & Precentral gyrus & 11 \\
\hline Broca parolfactory area & Parolfactory area & 11 \\
\hline Broca pouch & Pudendal sac & 11 \\
\hline Brodie bursa & Semimembranosus bursa & 12 \\
\hline Bruce tract & Septomarginal fasciculus & 11 \\
\hline Bruch glands & Trachoma glans & 11 \\
\hline
\end{tabular}




\begin{tabular}{|c|c|c|}
\hline Bruch membrane & Basal lamina of choroideae & 12 \\
\hline Brücke muscle & Part of ciliary muscle formed by the meridional fibres & 11 \\
\hline Brunner glands & Duodenal glands & 12 \\
\hline Buck fascia (penis) & Fascia of penis & 12 \\
\hline Buck fascia (perineum) & Perineal fascia; Superficial investing fascia of perineum; Deep perineal fascia & 12 \\
\hline Burdach nucleus & Cuneate nucleus & 12 \\
\hline Burdach tract & Cuneate fasciculus & 12 \\
\hline Burn (Burns) space/notch & Suprasternal space/notch & 11 \\
\hline Burn (Burns) ligament & Falciform margin of saphenous opening & 12 \\
\hline Burow vein & $\begin{array}{l}\text { Occasional vein passing from the inferior epigastric, sometimes receiving a tributary from } \\
\text { the urinary bladder, which empties into the portal vein }\end{array}$ & 7 \\
\hline Burow veins & Renal veins & 12 \\
\hline Ciaccio glands & Accessory lacrimal glands & 11 \\
\hline Cajal interstitial nucleus & Posterior/dorsal nucleus & 12 \\
\hline Calleja olfactory islets & Olfactory islets & 12 \\
\hline Calot triangle & Cystohepatic triangle & 12 \\
\hline Camper chiasm & Tendinous chiasm of digital tendons & 21 \\
\hline Camper fascia & Intermediate investing fascia & 12 \\
\hline Camper ligament & Perineal membrane & 4 \\
\hline Camper line & Line running from the inferior border of ala of nose to the superior border of tragus of ear & 20 \\
\hline Camper plane & $\begin{array}{l}\text { Plane running from the tip of anterior nasal spine (acanthion) to the centre of bony } \\
\text { external auditory meatus on the right and left sides }\end{array}$ & 20 \\
\hline Carabelli formation & $\begin{array}{l}\text { Anomalous tubercle on the lingual surface of mesiolingual cusp of a permanent } \\
\text { maxillary first molar }\end{array}$ & 12 \\
\hline Carus circle & Temporal line & 11 \\
\hline Carus curve & $\begin{array}{l}\text { Curve of pelvis; An imaginary curved line obtained from a mathematical formula, } \\
\text { supposed to indicate the outlet of pelvic canal }\end{array}$ & 11 \\
\hline Casserio fonticulus/fontanelle & Mastoid fontanelle/fontanel & 21 \\
\hline Casserio ganglion & Trigeminal ganglion & 11 \\
\hline Casserio ligament & Anterior ligament of malleus & 12 \\
\hline Casserio muscle & Brachialis muscle & 12 \\
\hline Casserio nerve & Musculocutaneous nerve & 12 \\
\hline Chassaignac space & Potential space between the pectoralis major and the mammary gland & 20 \\
\hline Chassaignac tubercle & Carotid tubercle & 12 \\
\hline Chaussier line & Anteroposterior line of corpus callosum as it appears on median section of brain & 11 \\
\hline Chievitz organ & $\begin{array}{l}\text { Normal epithelial structure, possibly a neurotransmitter, found at the angle of mandible } \\
\text { with branches of buccal nerve }\end{array}$ & 12 \\
\hline Chievitz organ & Juxta-oral organ & 12 \\
\hline Chopart joint & Transverse tarsal joint & 12 \\
\hline Chopart ligament & Bifurcate ligament & 12 \\
\hline Civinini ligament & Pterygospinus ligament & 11 \\
\hline Civinini process & Pterygospinus process & 11 \\
\hline Civininii canal & Anterior canaliculus of chorda tympani & 11 \\
\hline Clado anastomosis & $\begin{array}{l}\text { Anastomosis in the right suspensory ligament of ovary between the appendicular and } \\
\text { ovarian arteries }\end{array}$ & 20 \\
\hline Clado band & Suspensory ligament of ovary & 11 \\
\hline Clado ligament & Mesenteric fold running from the broad ligament on the right side to the appendix & 11 \\
\hline Clado point & $\begin{array}{l}\text { Point at the junction of interspinous and right semilunar lines, at the lateral border of } \\
\text { rectus abdominis muscle }\end{array}$ & 11 \\
\hline
\end{tabular}




\begin{tabular}{|c|c|c|}
\hline Clarke column/nucleus & Posterior/dorsal thoracic nucleus & 12 \\
\hline Claudius fossa & Ovarian fossa & 4 \\
\hline Cloquet canal & Hyaloid canal & 12 \\
\hline Cloquet fascia & Tissue closing the femoral ring & 1 \\
\hline Cloquet gland/node & Proximal deep inguinal lymph node & 12 \\
\hline Cloquet septum & Femoral septum & 21 \\
\hline Cloquet space & Space between the ciliary zonule and the vitreous body & 21 \\
\hline Colles fascia (penis) & Subcutaneous tissue of penis & 12 \\
\hline Colles fascia (perineum) & Membranous layer of perineal subcutaneous tissue & 12 \\
\hline Colles fascia (scrotum) & Dartos fascia; Superficial fascia of scrotum & 12 \\
\hline Colles ligament & Reflected ligament & 12 \\
\hline Colles space & Superficial perineal pouch & 11 \\
\hline Collier tract & Medial longitudinal fasciculus & 11 \\
\hline Cooper fascia & Cremasteric fascia & 12 \\
\hline Cooper ligament & Pectineal ligament & 12 \\
\hline Cooper ligament (breast) & Suspensory ligament of breast & 12 \\
\hline Cooper ligament (groin) & Pectineal ligament & 12 \\
\hline Corti arch & Arch formed by the junction of heads of Corti inner and outer pillar cells & 4 \\
\hline Corti auditory teeth & $\begin{array}{l}\text { Acoustic teeth; Tooth-shaped formations or ridges occurring on the vestibular lip } \\
\text { of limbus laminae spiralis of cochlear duct }\end{array}$ & 4 \\
\hline Corti canal/tunnel & $\begin{array}{l}\text { Spiral canal in the organ of Corti, formed by the outer and inner pillar cells or rods of Corti; } \\
\text { it is filled with fluid and occasionally crossed by nonmedullated nerve fibres }\end{array}$ & 4 \\
\hline Corti ganglion & Cochlear ganglion & 12 \\
\hline Corti membrane & Tectorial membrane & 11 \\
\hline Corti organ & Spiral organ & 12 \\
\hline Cotunnius canal/aqueduct & Vestibular aqueduct & 11 \\
\hline Cotunnius liquid & Perilymph & 11 \\
\hline Cotunnius nervus & Nasopalatine nerve & 11 \\
\hline Cotunnius space/sac & Endolymphatic sac & 11 \\
\hline Cowper gland & Bulbo-urethral gland & 12 \\
\hline Cowper fascia & Cremasteric fascia & 1 \\
\hline Cowper ligament & Part of fascia lata, which is anterior to and provides origin for fibres of pectineus muscle & 20 \\
\hline Crampton line & $\begin{array}{l}\text { Line from the apex of cartilage of last rib downward and forward nearly to the crest of } \\
\text { ilium, then forward parallel with it to a little below the anterior superior spine }\end{array}$ & 20 \\
\hline Crampton muscle & Part of ciliary muscle formed by the meridional fibres & 20 \\
\hline Cruveilhier fascia & Rectoprostatic fascia, subcutaneous tissue of perineum & 1 \\
\hline Cruveilhier fossa/fossa navicularis & Infraclavicular fossa, scaphoid fossa of sphenoid bone & 11 \\
\hline Cruveilhier joint & Median atlantoaxial joint & 11 \\
\hline Cruveilhier ligament & Plantar ligaments & 4 \\
\hline Cruveilhier nerve & Lingual branch of facial nerve; Vertebral nerve & 12 \\
\hline Cruveilhier plexuses & Posteriori cervical plexus; vertebral plexus & 12 \\
\hline Cruveilhier veins & Superior veins of cerebellar hemisphere & 7 \\
\hline Darkschewitsch nucleus & Nucleus of posterior commissure & 12 \\
\hline Darwin tubercle & Auricular tubercle of pinna/auricle & 12 \\
\hline Daubenton angle & Occipital angle of parietal bone & 11 \\
\hline Daubenton line & Line passing between the opisthion and the basion & 11 \\
\hline Daubenton plane & Plane of foramen magnum & 11 \\
\hline Deiter nucleus & Lateral vestibular nucleus & 12 \\
\hline
\end{tabular}




\begin{tabular}{|c|c|c|}
\hline Deiter terminal frames & $\begin{array}{l}\text { Plate-like structures in the organ of Corti uniting the outer phalangeal cells with Hensen } \\
\text { cells }\end{array}$ & 11 \\
\hline Demoursian tunica/membrane & Posteriori limiting lamina of cornea & 20 \\
\hline Denonvillier aponeurosis & $\begin{array}{l}\text { Rectovesical septum: a fascial layer that extends superiorly from the central tendon of } \\
\text { perineum to the peritoneum between the prostate and rectum }\end{array}$ & 4 \\
\hline Denonvillier fascia & $\begin{array}{l}\text { Fascia of individual organ; rectoprostatic fascia: fascial layer extending superiorly from the } \\
\text { perineal body to the floor of rectovesical pouch of peritoneum, extending between and } \\
\text { separating the prostate and base of urinary bladder anteriorly from the rectum posteriorly } \\
\text { and investing the seminal glands and ampullae of ductus deferens; it is the male equiva- } \\
\text { lent of cardinal ligament in forming the middle or central lamina of hypogastric sheath }\end{array}$ & 12 \\
\hline Denonvillier ligament & $\begin{array}{l}\text { Superior fascia of pelvic diaphragm; Puboprostatic ligament; Lateral puboprostatic } \\
\text { ligament }\end{array}$ & 12 \\
\hline Descartes organ & Pineal gland & 7 \\
\hline Descemet membrane & Posteriori limiting lamina of cornea & 12 \\
\hline Dorello canal & $\begin{array}{l}\text { Bony canal sometimes found at the tip of temporal bone enclosing the abducent nerve } \\
\text { and inferior petrosal sinus as these two structures enter the cavernous sinus }\end{array}$ & 27 \\
\hline Douglas fold & Recto uterine fold + & 12 \\
\hline Douglas pouch & Recto uterine pouch ㅇ & 12 \\
\hline Douglas semicircular line & Arcuate line of rectus sheath & 12 \\
\hline Doyère eminence & $\begin{array}{l}\text { Slightly elevated area of skeletal muscle fibre's surface that corresponds to the site of } \\
\text { motor endplate }\end{array}$ & 11 \\
\hline Drummond marginal artery & Marginal artery; Juxtacolic artery; Marginal arcate & 12 \\
\hline Duncan folds & Obsolete term for the folds on the peritoneal surface of uterus immediately after delivery & 11 \\
\hline Duncan ventricle & Cavity of septum pellucidum & 11 \\
\hline Dupre muscle & Articularis genus muscle & 11 \\
\hline Dupuytren canal & Diploic vein & 11 \\
\hline Dupuytren fascia & Palmar aponeurosis & 1 \\
\hline Duverney fissures/notch & Notch in cartilage of acoustic meatus & 20 \\
\hline Duverney foramen & $\begin{array}{l}\text { Epiploic foramen, the passage, below and behind the portal hepatis, connecting the two } \\
\text { sacs of the peritoneum. }\end{array}$ & 11 \\
\hline Duverney gland & Greater vestibular gland & 12 \\
\hline Duverney muscle & Orbicularis oculi muscle & 11 \\
\hline Eberth perithelium & Incomplete layer of connective tissue cells encasing the blood capillaries & 11 \\
\hline Ebner glands & $\begin{array}{l}\text { Serous glands of tongue opening into the foliate papillae as well as into the bottom of the } \\
\text { trough surrounding the circumvallate papillae }\end{array}$ & 4 \\
\hline Ebner reticulum & Network of nucleated cells in seminiferous tubules & 8 \\
\hline Ecker fissure & Petrooccipital fissure & 8 \\
\hline Edigner tract & Spinothalamic tract & 8 \\
\hline Edinger-Westphal nucleus & Visceral nucleus; Autonomic nucleus of oculomotor nerve & 12 \\
\hline Eglis glands & Small, inconstant mucous glands of ureter and renal pelvis & 7 \\
\hline Ehrenritter ganglion & Superior ganglion & 12 \\
\hline Englisch sinus & Inferior petrosal sinus & 7 \\
\hline Eustachian amygdale/tonsil & Tubal tonsil & 12 \\
\hline Eustachian cushsion & Torus tubarius & 11 \\
\hline Eustachian muscle & Tensor tympani muscle & 12 \\
\hline Eustachian tube & Pharyngotympanic tube; Auditory tube & 12 \\
\hline Eustachian tuber & Slight projection from the labyrinthine wall of middle ear below the fenestra vestibule & 11 \\
\hline Eustachian valve & Valve of inferior vena cava & 12 \\
\hline Exner plexus & $\begin{array}{l}\text { Plexus formed by tangential nerve fibres in the superficial plexiform or molecular layer of } \\
\text { cerebral cortex }\end{array}$ & 11 \\
\hline
\end{tabular}




\begin{tabular}{|c|c|c|}
\hline Fallopian arch/ligament & Inguinal ligament & 12 \\
\hline Fallopian canal & Facial canal & 12 \\
\hline Fallopian hiatus & Hiatus for greater petrosal nerve & 11 \\
\hline Fallopian tube & Uterine tube & 12 \\
\hline Farabeuf triangle & Triangle formed by the internal jugular and facial veins and the hypoglossal nerve & 20 \\
\hline Farre line & Line marking the insertion of mesovarium at the hilum of ovary & 20 \\
\hline Ferrein canal & Lacrimal pathway & 20 \\
\hline Ferrein cords & Vocal fold & 11 \\
\hline Ferrein hiatus & Hiatus for greater petrosal nerve & 20 \\
\hline Ferrein ligamentum & Lateral ligament of temporomandibular joint & 20 \\
\hline Ferrein pyramids/processus & Medullary rays of renal cortex & 12 \\
\hline Ferrein tube & Convoluted tubule of kidney & 20 \\
\hline Ferrein vasa abberentia & Biliary canaliculi that are not connected with hepatic lobule & 31 \\
\hline Fielding membrane & Tapetum & 11 \\
\hline Flechsig ground bundles & Fasciculus proprius anterior and fasciculus proprius lateralis & 11 \\
\hline Flechsig oval bundle & Septomarginal fasciculus & 12 \\
\hline Flechsig tract & Posterior spinocerebellar tract & 12 \\
\hline Fleischmann bursa & Sublingual bursa & 20 \\
\hline Flood ligament & Glenohumeral ligaments & 12 \\
\hline Flower bone & $\begin{array}{l}\text { Sutural bones present at the pterion or junction of parietal, frontal, greater wing } \\
\text { of sphenoid, and squamous portion of temporal bones }\end{array}$ & 11 \\
\hline Folian process & Anterior process of malleus & 12 \\
\hline Fontana canal & Scleral venous sinus & 4 \\
\hline Fontana spaces & Spaces of iridocorneal angle & 12 \\
\hline Forel decussation & Anterior tegmental decussation; Ventral medial nucleus & 11 \\
\hline Forel fields & Nuclei of perizonal fields $[\mathrm{H}, \mathrm{H} 1, \mathrm{H} 2]$ of hypothalamus & 12 \\
\hline Foville fasciculus/stria & Terminal stria & 3 \\
\hline Foville tract & Posterior spinocerebellar tract & 26 \\
\hline Frankenhäuser ganglion & Uterovaginal plexus & 12 \\
\hline Fritsch nerve & Terminal nerve & 28 \\
\hline Führer artery & Ascending branch of deep circumflex iliac artery & 12 \\
\hline Galeati glands & Intestinal glands & 11 \\
\hline Galen anastomosis/nerve & Communicating branch of internal laryngeal branch with recurrent laryngeal nerve & 11 \\
\hline Galen vein & Great cerebral vein & 12 \\
\hline Gallaudet fascia (abdomen) & Superficial investing fascia & 12 \\
\hline Gallaudet fascia (perineum) & Perineal fascia; Superficial investing fascia of perineum; Deep perinea fascia & 12 \\
\hline Ganser commissures & Dorsa supra-optic commissure & 12 \\
\hline Gantzer muscle & Accessory head of the flexor pollicis longus muscle & 2 \\
\hline Gartner duct/canal & Longitudinal duct of epoophoron & 12 \\
\hline Gasserian ganglion & Trigeminal ganglion & 12 \\
\hline Gennari stria/ine & Occipital stripe/line & 12 \\
\hline Gerdy fibrae & Superficial transverse metacarpal ligament & 11 \\
\hline Gerdy fontanelle & Posterior (sagittal) fontanelle & 11 \\
\hline Gerdy hyoid fossa & Carotid triangle & 11 \\
\hline Gerdy interatrial loop & $\begin{array}{l}\text { Muscular fasciculus in the interatrial septum of heart, passing backward from } \\
\text { the atrioventricular groove }\end{array}$ & 20 \\
\hline Gerdy ligament & Suspensory ligament of axilla & 12 \\
\hline
\end{tabular}




\begin{tabular}{|c|c|c|}
\hline Gerdy tubercle & $\begin{array}{l}\text { Tubercle on the anterolateral side of upper end of tibia giving attachment to the iliotibial } \\
\text { tract and some fibres of tibialis anterior muscle }\end{array}$ & 11 \\
\hline Gerlach anular tendon & Fibrocartilaginous ring of tympanic membrane & 11 \\
\hline Gerlach tonsil & Tubal tonsil & 12 \\
\hline Gerlach valve & Valve of vermiform appendix & 11 \\
\hline Gerlach valvula & Trabecular tissue of sclera & 11 \\
\hline Gerota capsule fascia & Renal fascia & 12 \\
\hline Gierke respiratory bundle & Solitary tract & 12 \\
\hline Giacomini fascia/frenulum & Thin anterior tail of dentate gyrus & 1 \\
\hline Gibson fascia & Part of uppermost section of endothoracic fasciae & 1 \\
\hline Gillette suspensory ligament & Cricoesophageal tendon & 20 \\
\hline Gimbernat ligament & Lacunar ligament & 12 \\
\hline Giraldés organ & Paradydimis & 12 \\
\hline Glaserian artery & Anterior tympanic artery & 11 \\
\hline Glaserian fissure & Petrotympanic fissure & 12 \\
\hline Gley glands & Parathyroid glands & 11 \\
\hline Glisson capsule & Fibrous capsule of liver; Perivascular fibrous hepatic capsule & 12 \\
\hline Glisson sphincter & Sphincter of hepatopancreatic ampulla & 11 \\
\hline Godman fascia & $\begin{array}{l}\text { Pretracheal fascia; an extension of pretracheal fascia into the thorax and on } \\
\text { to the pericardium }\end{array}$ & 1 \\
\hline Goll column/tract & Gracile fasciculus & 21 \\
\hline Goll nucleus & Gracile nucleus & 12 \\
\hline Gower(s) tract/column & Anterior spinocerebellar tract & 12 \\
\hline Graafian follicle & Vesicular ovarian follicle & 12 \\
\hline Grace of god fascia & Bicipital aponeurosis & 1 \\
\hline Gratiolet radiation & Optic radiation & 12 \\
\hline Gruber-Landzert fossa & Inferior duodenal fossa & 11 \\
\hline Grynfelt triangle & Superior lumbar triangle & 12 \\
\hline Gubler line & Level of superficial origin of trigeminus on the pons & 11 \\
\hline Gudden (von Gudden) commissure & Ventra supra-optic commissure & 12 \\
\hline Gudden (von Gudden) ganglion & Dorsal subdivision of the nucleus of the posterior commissure of midbrain & 12 \\
\hline Gudden (von Gudden) nucleus & Posterior/dorsal tegmental nucleus & 12 \\
\hline Gudden (von Gudden) tract & Mammillotegmental fasciculus & 12 \\
\hline Guéneau de Mussy point & $\begin{array}{l}\text { Point, painful on pressure, at the junction of a line prolonging the left border of sternum and } \\
\text { a horizontal line at the level of end of the bony portion of the tenth rib }\end{array}$ & 11 \\
\hline Guérin glands & Urethral glands of female & 4 \\
\hline Guérin valve & Valve of navicular fossa & 12 \\
\hline Günz ligament & Portion of superficial layer of obturator membrane & 11 \\
\hline Guthrie muscle & $\begin{array}{l}\text { External urethral sphincter } \\
\text { Deep transverse perineal muscle } \sigma^{\star}\end{array}$ & 12 \\
\hline Guttural duct & Auditory tube & 11 \\
\hline Guyon canal & Ulnar canal & 4 \\
\hline Guyon isthmus & Isthmus of uterus & 20 \\
\hline H fields & Nuclei of perizonal fields $[\mathrm{H}, \mathrm{H} 1, \mathrm{H} 2]$ of hypothalamus & 31 \\
\hline Halban fascia & Pubocervical fascia, vesicovaginal septum & 1 \\
\hline Haller ansa & Communicating branch of facial nerve with glossopharyngeal nerve & 20 \\
\hline Haller arches & Medial and lateral arcuate ligaments & 12 \\
\hline Haller artery & Dorsal pancreatic artery & 12 \\
\hline
\end{tabular}




\begin{tabular}{|c|c|c|}
\hline Haller cell & $\begin{array}{l}\text { Variant of ethmoidal air cell developing into the floor of orbit adjacent } \\
\text { to the natural ostium of maxillary sinus }\end{array}$ & 4 \\
\hline Haller circle & Vascular circle of optic nerve, areolar venous plexus & 20 \\
\hline Haller ductulus/vas aberrans & Inferior aberrant duct & 12 \\
\hline Haller habenula & Cordlike remains of vaginal process of peritoneum & 20 \\
\hline Haller insula/anulus & Doubling of thoracic duct for part of its course through the thorax & 20 \\
\hline Haller layer/tunica/lamina & Vascular layer/tunica/lamina of eyeball & 12 \\
\hline Haller lobules & Lobules of epididymis & 11 \\
\hline Haller plexus & $\begin{array}{l}\text { Nerve plexus of sympathetic filaments and branches of external laryngeal nerve } \\
\text { on the surface of inferior constrictor muscle of pharynx }\end{array}$ & 4 \\
\hline Haller rete & Rete testis & 12 \\
\hline Haller tribus/tripod & Coeliac trunk & 12 \\
\hline Haller unguis/spur & $\begin{array}{l}\text { Calcarine spur: the lower of two elevations on the medial wall of posterior horn of lateral } \\
\text { ventricle of brain, caused by the depth of calcarine sulcus }\end{array}$ & 11 \\
\hline Haller vascular tissue & Vascular lamina of choroid & 11 \\
\hline Hannover canal/spaces & Ciliary zonule & 12 \\
\hline Harris lines & Growth arrest lines of bones & 11 \\
\hline Hartmann pouch & Body of gallbladder; Pouch at the junction of neck of gallbladder and the cystic duct & 12 \\
\hline Hartwig layer/stratum & Epidermis & 7 \\
\hline Harvey duct & Ductus arteriosum & 20 \\
\hline Harvey ligament & Ligamentum arteriosum & 12 \\
\hline Hasner valve/fold & Lacrimal fold & 12 \\
\hline Haversian folds & Synovial folds & 12 \\
\hline Heister diverticulum & Bulb of jugular vein & 11 \\
\hline Heister valve & Spiral fold of cystic duct & 12 \\
\hline Held bundle & Tectospinal tract & 12 \\
\hline Held decussation & Crossing of some of fibres arising from the cochlear nuclei to form the lateral lemniscus & 11 \\
\hline Helmholtz axis ligament & $\begin{array}{l}\text { Ligament forming the axis about which the malleus rotates; it consists of two portions } \\
\text { extending from the anterior and the posterior borders, respectively, of tympanic notch } \\
\text { to the malleus }\end{array}$ & 11 \\
\hline Helweg tract & Spinoolivary tract; Olivospinal truct & 12 \\
\hline Henke space & Retropharyngeal space & 11 \\
\hline Henle ampulla & Ampulla of ductus deferens & 11 \\
\hline Henle ansa & Nephron loop & 4 \\
\hline Henle fenestrated elastic membrane & Elastic laminae of arteries & 11 \\
\hline Henle glands & Accessory lacrimal glands & 11 \\
\hline Henle ligament & Inguinal falx, Conjoint tendon & 12 \\
\hline Henle loop & Nephron loop & 31 \\
\hline Henle sheath & Endoneurium & 11 \\
\hline Henle spine & Suprameatal spine & 12 \\
\hline Hensen canal/duct & Ductus reunions & 11 \\
\hline Hensen stripe & Band on the undersurface of membrana tectoria of cochlear duct & 11 \\
\hline Hering nerve & Carotid branch of glossopharyngeal nerve & 11 \\
\hline Herophilus torcular & Confluence of sinuses & 12 \\
\hline Heschl transverse convolutions & Transverse temporal gyri & 12 \\
\hline Hesselbach fascia & Cribriform fascia & 12 \\
\hline Hesselbach ligament & Interfoveolar ligament & 12 \\
\hline Hesselbach triangle & Inguinal triangle & 12 \\
\hline
\end{tabular}




\begin{tabular}{|c|c|c|}
\hline Heubner recurrent artery & Distal medial striate artery & 12 \\
\hline Hey ligament & Falciform margin of saphenous opening & 12 \\
\hline Highmore antrum & Maxillary sinus & 12 \\
\hline Highmore body & Mediastinum of testis & 12 \\
\hline Hilton sac & Laryngeal saccule/sac & 11 \\
\hline Hilton waterbed & Pontocerebellar cistern & 12 \\
\hline Hilton white line & $\begin{array}{l}\text { Bluish pink, narrow, wavy zone in the mucosa of anal canal below the pectinate line at } \\
\text { the level of interval between the subcutaneous part of external sphincter and the lower } \\
\text { border of internal sphincter }\end{array}$ & 11 \\
\hline Hippocrates chorda magna & Calcaneal tendon & 7 \\
\hline Hirschfeld canals & $\begin{array}{l}\text { Interdental canal: canals that extend vertically through interdental alveolar bone between } \\
\text { roots of mandibular and maxillary incisors and maxillary bicuspid teeth }\end{array}$ & 11 \\
\hline Hirschfeld nerve & Abducent nerve & 7 \\
\hline His angle & Cardiac notch & 12 \\
\hline His bundle & Atrioventricular bundle & 12 \\
\hline His canal & Thyroglossal duct & 6 \\
\hline His copula & Hypopharyngeal eminence & 6 \\
\hline His spindle & Aortic spindle: fusiform dilation of aorta immediately beyond the isthmus & 6 \\
\hline His-Tawara system & Complex system of interlacing Purkinje fibres within the ventricular myocardium & 6 \\
\hline Hoche bundle tract & Interfascicular fasciculus & 12 \\
\hline Hoffman duct & Pancreatic duct & 11 \\
\hline Home lobe & Middle lobe of prostate & 11 \\
\hline Horner muscle & Deep part of orbicularis oculi muscle & 12 \\
\hline Houston valve & Transverse folds of rectum & 12 \\
\hline Hueck ligament & Trabecular tissue of sclera & 11 \\
\hline Huguier canal & Anterior canaliculus of chorda tympani & 11 \\
\hline Huguier circle & Anastomosis around the isthmus of uterus between the right and left uterine arteries & 11 \\
\hline Huguier sinus & Fossa of oval window & 11 \\
\hline Humphrey ligament & Anterior meniscofemoral ligament & 12 \\
\hline Hunter canal & Adductor canal & 12 \\
\hline Hunter gubernaculum & Gubernaculum testis & 11 \\
\hline Hunter ligament & Round ligament of uterus & 12 \\
\hline Hunter line & Linea alba & 11 \\
\hline Hunter-Schreger bands & $\begin{array}{l}\text { Light and dark lines seen in enamel of tooth that begin at the dentoenamel junction } \\
\text { and end before they reach the enamel surface }\end{array}$ & 11 \\
\hline Huschke cartilage & Vomeronasal cartilage & 12 \\
\hline Huschke cartilages & Two horizontal cartilaginous rods at the edge of cartilaginous septum of nose & 11 \\
\hline Huschke foramen & $\begin{array}{l}\text { Opening in the floor of bony part of external acoustic meatus near the tympanic } \\
\text { membrane, normally closed in the adult }\end{array}$ & 4 \\
\hline Huschke recessus & Paraduodenal recess & 11 \\
\hline Huschke teeth & Acoustic teeth & 11 \\
\hline Huschke valve & Lacrimal fold & 11 \\
\hline Hyrtl fascia & Transversalis fascia & 1 \\
\hline Hyrtl muscle & lliopsoas muscle & 12 \\
\hline Hyrtl recessus & Epitympanum & 11 \\
\hline Ingrassia process & Lesser wing & 12 \\
\hline Jackson fascia & Precaecocolic fascia & 1 \\
\hline Jackson membrane veil & Precaecocolic fascia & 12 \\
\hline Jacobson canaliculus & Tympanic canaliculus & 12 \\
\hline
\end{tabular}




\begin{tabular}{|c|c|c|}
\hline Jacobson cartilage & Vomeronasal cartilage & 12 \\
\hline Jacobson nerve & Tympanic nerve & 12 \\
\hline Jacobson organ & Vomeronasal organ & 12 \\
\hline Jacobson plexus & Tympanic plexus & 12 \\
\hline Jobert de Lamballe fossa & $\begin{array}{l}\text { Hollow or furrow just above the knee formed by the adductor magnus and the sartorius } \\
\text { and gracilis }\end{array}$ & 11 \\
\hline Jung muscle & Pyramidal muscle of auricle & 11 \\
\hline Kadyi cauda & Cauda equina & 26 \\
\hline Kaes-Bechterew band & Myelinated fibres in the most superficial part of third layer of isocortex & 11 \\
\hline Kappa angle & Angle between the pupillary axis and the visual axis & 20 \\
\hline Keith-Flack node & Sinoatrial node & 12 \\
\hline Kent bundle & Atrioventricular bundle & 12 \\
\hline Kerckring folds/valves & Circular folds of small intestine & 12 \\
\hline Kerckring nodules & Nodules of semilunar cusps & 24 \\
\hline Kerckring ossicle/centre & $\begin{array}{l}\text { Occasional independent ossification centre in the occipital bone; it appears in the } \\
\text { posterior margin of foramen magnum at about the sixteenth week of gestation }\end{array}$ & 11 \\
\hline Key-Retzius foramen & Lateral aperture of fourth ventricle & 12 \\
\hline Key-Retzius sheath & Endoneurium & 11 \\
\hline Kilian line & Transverse line marking the promontory of pelvis & 11 \\
\hline Killian bundle/muscle & Inferior constrictor muscle of pharynx & 11 \\
\hline Killian tringle & $\begin{array}{l}\text { Triangular area of cenvical oesophagus bordered by the oblique fibres of inferior } \\
\text { constrictor muscle of pharynx and the transverse fibres of cricopharyngeus muscle }\end{array}$ & 11 \\
\hline Killian-Jamieson area & $\begin{array}{l}\text { Area bounded superiorly by the lowest cricopharyngeal fibres and inferiorly by the upper } \\
\text { circular fibres of oesophagus }\end{array}$ & 11 \\
\hline Klaes-Bechterew band stripe & Stria of molecular layer & 12 \\
\hline Klein muscle & Orbicularis oris muscle & 11 \\
\hline Kobelt tubules & Epoophoron & 31 \\
\hline Kobelt tubules & Remnants of mesonephric tubules in the female, contained within the epoophoron & 11 \\
\hline Koch node & Sinoatrial node & 12 \\
\hline Koch triangle & Triangle of sinoatrial/atrioventricular node & 12 \\
\hline Kohlrausch fold & Middle transverse fold of rectum & 12 \\
\hline Kohlrausch muscle & Longitudinal muscles of rectal wall & 11 \\
\hline Kölliker-Fuse nucleus & Subparabrachial nucleus & 12 \\
\hline Koyter muscle & Corrugator supercilii muscle & 12 \\
\hline Krause bone & $\begin{array}{l}\text { Secondary ossification centre in the triradiate cartilage temporarily existing as a small } \\
\text { bone between the ilium, the ischium, and the pubic bone in the growing acetabulum }\end{array}$ & 11 \\
\hline Krause end bulbs & $\begin{array}{l}\text { Nerve terminals in skin, mucosa of oral cavity, conjunctiva, and other parts, consisting of } \\
\text { a laminated capsule of connective tissue enclosing the terminal, branched, convoluted } \\
\text { ending of an afferent nerve fibre; generally believed to be sensitive to touch and pressure }\end{array}$ & 11 \\
\hline Krause glands & Accessory lacrimal glands; Glands of tympanic cavity & 12 \\
\hline Krause ligament & Transverse perineal ligament, Transverse suspensorium bulbi ligament & 11 \\
\hline Krause respiratory bundle & Solitary tract & 11 \\
\hline Krause valve/fold & Fold in the interior of lacrimal sac at its junction with the lacrimal duct & 11 \\
\hline Krukenberg spindle & Vertical fusiform area of melanin pigmentation on the posterior surface of central cornea & 31 \\
\hline Krukenberg veins & Central veins of liver & 11 \\
\hline Kugel anastomotic artery & Atrial anastomotic branch of circumflex branch of left coronary artery & 11 \\
\hline Labbé vein & Superficial middle cerebral vein & 12 \\
\hline Laimer-Haeckerman area & $\begin{array}{l}\text { Triangular (or V-shaped) area on the posterior aspect of proximal oesophagus, with its } \\
\text { apex directed inferiorly in the midline and the cricopharyngeus muscle forming its base }\end{array}$ & 11 \\
\hline
\end{tabular}




\begin{tabular}{|c|c|c|}
\hline Lallouette pyramid & Pyramidal lobe of thyroid gland & 12 \\
\hline Lancisi stria & Medial longitudinal stria & 12 \\
\hline Landström muscle & $\begin{array}{l}\text { Muscle fibres in the fascia behind and about the eyeball, attached anteriorly to the lids } \\
\text { and anterior orbital fascia }\end{array}$ & 11 \\
\hline Landzert fossa & $\begin{array}{l}\text { Fossa formed by two peritoneal folds, enclosing the left colic artery and the inferior } \\
\text { mesenteric vein, respectively, at the side of duodenum }\end{array}$ & 20 \\
\hline Langenbeck nerves & Supraclavicular nerves & 7 \\
\hline Langenbeck triangle & $\begin{array}{l}\text { Triangle formed by lines drawn from the anterior superior iliac spine to the surface of } \\
\text { great trochanter and to the surgical neck of femur }\end{array}$ & 11 \\
\hline Langer arch/muscle & Pectorodorsalis muscle & 11 \\
\hline Langer line & Tension lines of skin & 12 \\
\hline Langerhans islets & Pancreatic islets & 12 \\
\hline Langley nerves & Pilomotor nerves, Pelvic splanchnic nerves & 20 \\
\hline Langley system & Sympathetic part of autonomic system & 7 \\
\hline Lannelongue foramina & Openings of smallest cardiac veins & 8 \\
\hline Lannelongue ligaments & Sternopericardial ligaments & 8 \\
\hline Lanterman segments & Divisions of nerve fibre between the Schmidt-Lanterman incisures & 11 \\
\hline Lanz linea & Interspinous line/plane & 7 \\
\hline Larrey trigonum & Sternocostal triangle & 31 \\
\hline Latarget (Latarjet) plexus & Superior hypogastric plexus & 7 \\
\hline Latarget vein & Prepyloric vein & 11 \\
\hline Latarjet (Latarget) anterior/posterior nerve & Anterior/posterior nerve of lesser curvature of anterior/posterior vagal trunk & 12 \\
\hline Laumonier ganglion & Carotid ganglion & 11 \\
\hline Lauth canalis & Scleral venosus sinus & 20 \\
\hline Lauth ligament & Transverse ligament of atlas & 11 \\
\hline Leber muscles & Rectus abdominis muscles & 7 \\
\hline Leber plexus & $\begin{array}{l}\text { Venous plexus in the eye between the venous sinuses of sclera and the spaces } \\
\text { of iridocorneal angle }\end{array}$ & 11 \\
\hline Lecomte pronator of ulna & Articularis cubiti muscle & 12 \\
\hline Lenhossek fibrae/formation & Reticular formation & 20 \\
\hline Lenhossék processes & Short processes ("aborted axons") possessed by some ganglion cells & 21 \\
\hline Leonardo (da Vinci) cord & Septomarginal trabecula & 12 \\
\hline Lesshaft space triangle & Superior lumbar triangle & 12 \\
\hline Lieberkűhn crypts & Intestinal glands & 12 \\
\hline Lieutaud triangle & Trigone of bladder & 12 \\
\hline Lieutaud uvula & Uvula of bladder & 20 \\
\hline Lisfranc joint & Tarsometatarsal joints & 12 \\
\hline Lisfranc ligament & Medial cuenometatarsal interosseous ligaments & 12 \\
\hline Lisfranc tubercle & Scalene tubercle & 12 \\
\hline Lissauer tract/zone & Posterolateral tract; Dorsolateral tract & 12 \\
\hline Lister tubercle & Ulnar styloid process; Dorsal tubercle of radius & 12 \\
\hline Littre glands & Urethral glands & 12 \\
\hline Lockwood ligament & Suspensory ligament of eyeball & 31 \\
\hline Louis angle & Sternal angle & 31 \\
\hline Lovibond angle & $\begin{array}{l}\text { Angle made at the meeting of proximal nail fold and the nail plate when viewed } \\
\text { from the radial aspect }\end{array}$ & 11 \\
\hline Löwenberg canalis/scala & Cochlear duct & 11 \\
\hline Loewenthal tract & Tectospinal tract & 11 \\
\hline Lower rings & Right and left fibrous rings of heart & 20 \\
\hline
\end{tabular}




\begin{tabular}{|c|c|c|}
\hline Lower tubercle & Intervenous tubercle of right atrium & 12 \\
\hline Ludwig (Ludovicus) angle & Sternal angle & 12 \\
\hline Ludwig (Ludovicus) ganglion & Collection of parasympathetic nerve cells in the interatrial septum & 11 \\
\hline Ludwig (Ludovicus) labyrinth & Convoluted part of kidney lobule & 11 \\
\hline Ludwig (Ludovicus) nerve & Aortic nerve & 11 \\
\hline Luschka bursa & Pharyngeal bursa & 11 \\
\hline Luschka cartilage & Small cartilaginous nodule found in the anterior portion of vocal cord & 11 \\
\hline Luschka cystic glands & $\begin{array}{l}\text { Glans of biliary mucosa: small, mucous, tubuloalveolar glands in the mucosa } \\
\text { of larger bile ducts and especially in the neck of gallbladder }\end{array}$ & 5 \\
\hline Luschka ducts & Glandlike tubular structures in the wall of gallbladder & 5 \\
\hline Luschka foramen & Lateral aperture of fourth ventricle & 12 \\
\hline Luschka glands/tonsil & Pharyngeal tonsil; Coccygeal body & 12 \\
\hline Luschka joints & Uncovertebral joints & 4 \\
\hline Luschka ligaments & Sternopericardial ligaments & 11 \\
\hline Luschka nerve & Arterior ethmoidal nerve; spheno-ethmoidal nerve & 11 \\
\hline Luschka recurrent nerve & Meningeal/recurrent branch of spinal nerve & 12 \\
\hline Luschka sinus & Venous sinus in petrosquamous suture & 11 \\
\hline Luys body/corpus/nucleus & Subthalamic nucleus & 12 \\
\hline Lyra davidis & Commissura fornix & 4 \\
\hline Lyra uterina & Palmate folds of cervical canal & 11 \\
\hline Macalister fascia & Triangular fascia & 1 \\
\hline Macewen triangle & Suprameatal triangle & 12 \\
\hline Mackenrodt ligament & Cardinal ligament; Transverse cervical ligament & 12 \\
\hline Magendie foramen & Median aperture of fourth ventricle & 12 \\
\hline Magendie space & Subarachnoid space at the level of fissures of brain & 11 \\
\hline Maier sinus & Fornix of lacrimal sac & 11 \\
\hline Maissiat bandelette & lliotibial tract & 12 \\
\hline Malcerne pyramid & Posterior portion of cerebellar vermis & 20 \\
\hline Malcerne space & Posterior perforated substance & 7 \\
\hline Malgaigne fossa/triangle & Carotid triangle & 11 \\
\hline Mall ridges & Pulmonary bridges & 20 \\
\hline Malone ganglion & Supraoptic nucleus & 20 \\
\hline Malone nucleus & Nuclei of perizonal fields $[\mathrm{H}, \mathrm{H} 1, \mathrm{H} 2]$ of hypothalamus & 20 \\
\hline Malpighian bodies/glands/corpuscle & Splenic pulp (splenic lymph follicles); Renal corpuscle & 4 \\
\hline Malpighian canal & Longitudinal duct & 12 \\
\hline Malpighian capsule & Fibrous capsule of spleen & 12 \\
\hline Malpighian stigmas & Points of entrance of smaller veins into the larger veins of spleen & 11 \\
\hline Malpighian stratum/layer/rete & Living layer of epidermis comprising the stratum basale, and stratum spinosum & 31 \\
\hline Malpighian vesicles & Minute air-filled vesicles on the surface of an expanded lung & 11 \\
\hline Marchand glandules/adrenals/rest & $\begin{array}{l}\text { Small conglomerations of accessory glandular tissue in the broad ligament of uterus } \\
\text { or in the testes }\end{array}$ & 11 \\
\hline Marie tract & Sulcomarginal fasciculus & 12 \\
\hline Mariotte disc/blind spot & Optic disc & 11 \\
\hline Marshall oblique vein & Oblique vein of left atrium & 12 \\
\hline Marshall vein & Oblique vein of left ventricle & 20 \\
\hline Marshall vestigial fold & Vestigial fold of superior vena cava & 20 \\
\hline Martegiani area/funnel & Funnel-shaped dilation on the optic disc that indicates the beginning of hyaloid canal & 11 \\
\hline Mauchart ligament & Alar ligaments & 12 \\
\hline
\end{tabular}




\begin{tabular}{|c|c|c|}
\hline Mayer ligament & Palmar radiocarpal ligament & 20 \\
\hline Mayo vein & Prepyloric vein & 12 \\
\hline McBurney point & $\begin{array}{l}\text { Point between } 3 \text { and } 5 \mathrm{~cm} \text { superomedial to the anterior superior iliac spine, } \\
\text { on a line joining that process and the umbilicus }\end{array}$ & 4 \\
\hline Meckel band/igament & $\begin{array}{l}\text { Portion of anterior ligament of malleus that extends from the base of anterior process } \\
\text { through the petrotympanic fissure to attach to the spine of sphenoid }\end{array}$ & 11 \\
\hline Meckel cave/space & Trigeminal cave/cavity & 12 \\
\hline Meckel diverticulum & lleal diverticulum & 12 \\
\hline Meckel eminentia & Collateral eminence behind the main part of hippocampus & 24 \\
\hline Meckel ganglion & Pterygopalatine ganglion & 12 \\
\hline Meckel groove & Trigeminal impression & 12 \\
\hline Meckel plane & Craniometric plane cutting the alveolar and the auricular points & 3 \\
\hline Meibomian glands & Tarsal glands & 12 \\
\hline Meissner plexus & Submucous plexus (part of enteric autonomic plexus) & 12 \\
\hline Mercier bar & Ureteric orifice & 12 \\
\hline Mercier plica & Interureteric crest & 7 \\
\hline Mercier valve & Occasional fold of mucosa of bladder partially occluding the ureteral orifice & 11 \\
\hline Merkel filtrum ventriculi & $\begin{array}{l}\text { Filtrum ventriculi: groove between the two prominences, in each lateral wall of vestibule } \\
\text { of larynx, formed by the cuneiform and the arytenoid cartilages }\end{array}$ & 11 \\
\hline Merkel fossa & $\begin{array}{l}\text { Groove in the posterolateral wall of vestibule of larynx between the corniculate and } \\
\text { cuneiform cartilages }\end{array}$ & 4 \\
\hline Merkel muscle & Ceratocricoid muscle & 11 \\
\hline Merkel tactile disc & $\begin{array}{l}\text { Tactile meniscus: specialized tactile sensory nenve ending in the epidermis, characterised } \\
\text { by a terminal cuplike expansion of an intraepidermal axon in contact with the base of } \\
\text { a single Merkel cell }\end{array}$ & 11 \\
\hline Méry gland & Bulbourethral gland & 7 \\
\hline Meyer cartilage & Anterior sesamoid cartilages at the anterior attachments of vocal ligaments & 11 \\
\hline Meyer line & Line through the axis of big toe and passing the midpoint of heel in a normal foot & 11 \\
\hline Meyer sinus & Small concavity in the floor of external auditory canal near the membrana tympani & 11 \\
\hline Meyer sulcus & Olfactory region of nasal mucosa & 7 \\
\hline Meynert cells & Solitary pyramidal cells found in the cortex in the region of calcarine fissure & 11 \\
\hline Meynert commissure & Dorsal supra-optic commissure & 12 \\
\hline Meynert decussation & Posterior/dorsal tegmental decussation & 12 \\
\hline Meynert nucleus & Basal nucleus & 12 \\
\hline Meynert retroflex bundle & Retroflex fasciculus & 12 \\
\hline Meynert retroflex bundle & Habenulo-interpeduncular tract; Fasciculus retroflexus & 11 \\
\hline Michels artery & Retroduodenal arteries & 12 \\
\hline Mohrenheim fossa & Infraclavicular fossa & 12 \\
\hline Moll glands & Ciliary glands & 12 \\
\hline Monakow nucleus & Accessory cuneate nucleus & 11 \\
\hline Monakow tract/bundle & Rubrospinal tract & 12 \\
\hline Monro foramen & Interventricular foramen & 12 \\
\hline Monro gland & Palpebral part of lacrimal gland & 11 \\
\hline Monro line & Line passing from the umbilicus to the anterior superior iliac spine & 11 \\
\hline Monro sulcus & Hypothalamic sulcus & 11 \\
\hline Monro-Richter line & Line passing from the umbilicus to the anterior superior iliac spine & 11 \\
\hline Montgomery glands/follicles & Areolar glands & 31 \\
\hline Montgomery tubercles & Areolar tubercle & 12 \\
\hline
\end{tabular}




\begin{tabular}{|c|c|c|}
\hline Morand calcar & $\begin{array}{l}\text { Calcarine spur: the lower of two elevations on the medial wall of posterior horn of lateral } \\
\text { ventricle of brain, caused by the depth of calcarine sulcus }\end{array}$ & 31 \\
\hline Morand foramen & Foramen caecum of tongue & 12 \\
\hline Morgagni appendix & Pyramidal lobe of thyroid gland & 11 \\
\hline Morgagni cartilage/tubercle & Cuneiform cartilage & 12 \\
\hline Morgagni caruncle & Middle lobe of prostate & 11 \\
\hline Morgagni columns & Anal columns & 12 \\
\hline Morgagni concha & Superior nasal concha & 11 \\
\hline Morgagni crypts/sinus & Anal sinuses & 11 \\
\hline Morgagni foramen/retinaculum & Foramen caecum of tongue; Foramina nervosa & 12 \\
\hline Morgagni fossa/fovea & Navicular fossa of male urethra & 11 \\
\hline Morgagni frenulum/frenum & Frenulum of ileal orifice & 4 \\
\hline Morgagni humour/liquor & $\begin{array}{l}\text { Fluid found postmortem between the epithelium and the fibres of lens, resulting from the } \\
\text { liquefaction of a semifluid material that exists there during life }\end{array}$ & 11 \\
\hline Morgagni hydatid & Vesicular appendices, Appendix of testis & 12 \\
\hline Morgagni hydatid/cyst & Vesicular appendages of epoophoron & 12 \\
\hline Morgagni lacunae & Urethral lacunae & 12 \\
\hline Morgagni nodules & Nodules of semilunar cusps & 12 \\
\hline Morgagni triangle & Sternocostal triangle & 12 \\
\hline Morgagni tuberculum & Olfactory bulb & 20 \\
\hline Morgagni valves & Anal valves & 11 \\
\hline Morgagni ventricle & Laryngeal ventricle & 31 \\
\hline Morison pouch & Hepatorenal recess & 12 \\
\hline Morton plane & Plane passing through the summits of parietal and occipital protuberances & 20 \\
\hline Múller capsula & Glomerular capsule & 11 \\
\hline Múller fibres & $\begin{array}{l}\text { Sustentacular neuroglial cells of retina, running through the thickness of retina from the } \\
\text { internal limiting membrane to the bases of rods and cones where they form a row of } \\
\text { junctional complexes }\end{array}$ & 11 \\
\hline Múller muscle & Circular fibres of ciliary muscle; Orbital muscle, Superior tarsal muscle & 12 \\
\hline Müller trigone & Floor of supraoptic recess of third ventricle & 11 \\
\hline Naboth glands & Cervical glands & 4 \\
\hline Nélaton line & Line drawn from the anterior superior iliac spine to the tuberosity of the ischium & 31 \\
\hline Neubauer artery & Thyroid ima artery & 11 \\
\hline Neumann sheath & Uncalcified bone matrix between an osteocyte and the lacunar or canalicular wall & 11 \\
\hline Nuck canal & Processus vaginalis of peritoneum & 31 \\
\hline Nuhn gland & Lingual glands & 12 \\
\hline Oddi sphincter & Sphincter of pancreatoduodenal ampulla & 12 \\
\hline Onuf nucleus & $\begin{array}{l}\text { Nucleus of pudendal nerve: a group of small, somatic, motor neurons in the ventral horn } \\
\text { of spinal cord at sacral } 2 \text { level that innervate the vesicorectal sphincters }\end{array}$ & 12 \\
\hline Pacchioni bodies/corpuscles/glands & Arachnoid granulations & 4 \\
\hline Pacchioni foramen & Tentorial notch & 11 \\
\hline Pacchionian granulations/depressions & Arachnoid granulations; Granular foveolae & 12 \\
\hline Paladino-His fasciculus & Atrioventricular bundle & 6 \\
\hline Pansch fissure & $\begin{array}{l}\text { Cerebral fissure running from the lower extremity of central fissure nearly to the end of } \\
\text { the occipital lobe }\end{array}$ & 11 \\
\hline Parona space & $\begin{array}{l}\text { Deep part of anterior compartment of forearm; Space between the pronator quadratus } \\
\text { deep and the overlying flexor tendons of the forearm that is continuous through the } \\
\text { carpal tunnel with the medial central palmar space }\end{array}$ & 12 \\
\hline Passavant ridge/bar & Palatopharyngeal ridge & 12 \\
\hline
\end{tabular}




\begin{tabular}{|c|c|c|}
\hline Pavlov nerve & Inferior cervical cardiac nerve & 12 \\
\hline Pechlin glands & Duodenal glands & 7 \\
\hline Pecquet cistern/reservoir & Cisterna chili & 12 \\
\hline Pecquet duct/canal & Thoracic duct & 11 \\
\hline Petit canal, spaces & Zonular spaces & 12 \\
\hline Petit ligament & Uterosacral ligament; Recto-uterine ligament & 12 \\
\hline Petit triangle & Inferior lumbar triangle & 12 \\
\hline Peyer patches & Aggregated lymphoid nodules & 12 \\
\hline Philip glands & $\begin{array}{l}\text { Submandibular lymphatic nodes; supraclavicular lymphatic nodes, common } \\
\text { iliac lymphatic nodes }\end{array}$ & 7 \\
\hline Phillipe-Gombault triangle & Interfascicular fasciculus & 12 \\
\hline Pirogov (Pirogoff) aponeurosis & Coracobrachialis & 12 \\
\hline Pirogov (Pirogoff) angle & Venous (venal) angle & 4 \\
\hline Pirogov (Pirogoff) aponeurosis & Bicipital aponeurosis & 12 \\
\hline Pirogov (Pirogoff) triangle & Hypoglossohyoid triangle & 4 \\
\hline Poirier gland & Lymph node on the uterine artery where it crosses the ureter & 11 \\
\hline Porter fascia & Pretracheal layer of cervical fascia & 1 \\
\hline Poupart ligament & Inguinal ligament & 12 \\
\hline Prussak fibres & Elastic and connective tissue fibres bounding the pars flaccida membranae tympani & 8 \\
\hline Prussak space/pouch & Superior recess of tympanic membrane & 4 \\
\hline Purkinje cell layer & Purkinje cell layer of cerebellar cortex & 12 \\
\hline Purkinje fibres/system/network & Subendocardial branches of conducting cardiac system & 12 \\
\hline Quain fascia & Triangular, reflex inguinal ligament & 1 \\
\hline Quatrefages angle & $\begin{array}{l}\text { Parietal angle: angle formed by the meeting of prolongation of two lines tangential to the } \\
\text { most prominent part of the zygomatic arch and to the parietofrontal suture on each side }\end{array}$ & 21 \\
\hline Quénu haemorrhoidal plexus & Lymphatic plexuses in the anal skin & 11 \\
\hline Quervain (de Quervain) vagina/sheath & Tendinous sheath & 4 \\
\hline Rappaport acinus & Liver acinus & 11 \\
\hline Rasmussen bundle & Olivocochlear tract & 12 \\
\hline Rathke bundles/trabeculae & Trabeculae carneae of cardiac ventricles & 4 \\
\hline Rathke diverticulum/packet/pouch & Adenohypophysial diverticulum & 31 \\
\hline Rau process & Anterior process of malleus & 12 \\
\hline Ravius process & Anterior process of malleus & 11 \\
\hline Reichert membrane & Anterior limiting lamina & 12 \\
\hline Reichert recess & Cochlear recess & 11 \\
\hline Reil ansa & Peduncular ansa & 4 \\
\hline Reil band & Septomarginal trabecula & 20 \\
\hline Reil island & Insula; Insular lobe & 12 \\
\hline Reil lemniscus/ribbon & Medial lemniscus & 11 \\
\hline Reil sulcus & Circular sulcus of insula & 11 \\
\hline Reil tract & Parietopontine fibres & 4 \\
\hline Reil triangle & Trigone of lateral lemniscus & 11 \\
\hline Reinke space & $\begin{array}{l}\text { Potential space between the lamina propria and the external elastic lamina } \\
\text { of the vocal fold }\end{array}$ & 31 \\
\hline Reisseisen muscles & Smooth muscle fibres in the smallest bronchial tubes & 11 \\
\hline Reissner canal & Cochlear duct & 12 \\
\hline Reissner fibre & $\begin{array}{l}\text { Rodlike, highly refractive fibre running caudally from the subcommissural organ } \\
\text { throughout the length of the central canal of the brainstem and spinal cord }\end{array}$ & 31 \\
\hline
\end{tabular}




\begin{tabular}{|c|c|c|}
\hline Reissner membrane & Vestibular surface of cochlear duct & 12 \\
\hline Reissner membrane & Vestibular surface/membrane & 12 \\
\hline Remak fibres & Unmyelinated fibres & 11 \\
\hline Remak ganglia & $\begin{array}{l}\text { Groups of nerve cells in the wall of venous sinus where it joins the right atrium of the } \\
\text { heart; Autonomic ganglia in nerves of stomach }\end{array}$ & 20 \\
\hline Remak plexus & Submucous plexus (part of enteric autonomic plexus) & 12 \\
\hline Retzius band & Fundiform ligament of clitoris +9 & 12 \\
\hline Retzius cave/cavity/space & Retropubic space & 12 \\
\hline Retzius foramen & Lateral aperture of fourth ventricle & 11 \\
\hline Retzius gyrus & Fundiform ligament of foot: the intralimbic gyrus in the cortical portion of rhinencephalon & 11 \\
\hline Retzius ligament & Deep attachment of inferior extensor retinaculum in the tarsal sinus & 11 \\
\hline Retzius lines & $\begin{array}{l}\text { Calcification lines: incremental lines of rhythmic deposition of successive layers of } \\
\text { normally calcified and hypocalcified enamel during tooth development }\end{array}$ & 11 \\
\hline Retzius striae & $\begin{array}{l}\text { Dark, concentric lines crossing the enamel prisms of teeth seen in axial } \\
\text { cross-sections of the enamel }\end{array}$ & 11 \\
\hline Retzius veins & Retroperitoneal veins & 11 \\
\hline Richard fimbria & Ovarian fimbria & 11 \\
\hline Richet fascia & Fold of extraperitoneal fasciae enveloping the obliterated umbilical vein & 1 \\
\hline Richet fascia/aponeurosis & Cenvico-pericardial fascia, clavipectoral fascia & 1 \\
\hline Richter-Monro line & Line passing from the umbilicus to the anterior superior iliac spine & 20 \\
\hline Ridley circle/sinus & Intercavernous sinuses & 11 \\
\hline Riedel lobe & $\begin{array}{l}\text { Occasional tongue-like process extending downward from the right lobe of } \\
\text { liver lateral to the gallbladder }\end{array}$ & 11 \\
\hline Riolan arcade/arc & $\begin{array}{l}\text { Intestinal arterial arcades: marginal artery, juxtacolic artery and marginal arcade } \\
\text { of superior mesenteric artery }\end{array}$ & 12 \\
\hline Riolan bones & Small sutural bones sometimes present in the petrooccipital suture & 11 \\
\hline Riolan bouquet & Muscles and ligament arising from the styloid process of temporal bone & 11 \\
\hline Riolan fasciculus & Ciliary bundle of palpebral part of orbicularis oculi muscle & 20 \\
\hline Riolan muscle & Cremaster muscle; Ciliary bundle of palpebral part of orbicularis oculi muscle & 12 \\
\hline Rivinus duct & Minor sublingual duct & 12 \\
\hline Rivinus gland & Sublingual gland & 12 \\
\hline Rivinus membrane & Tympanic membrane & 12 \\
\hline Rivinus notch/incisure & $\begin{array}{l}\text { Tympanic notch: notch in the superior part of tympanic ring bridged by the flaccid part of } \\
\text { tympanic membrane }\end{array}$ & 12 \\
\hline Robert ligament & Posteriori meniscofemoral ligament & 12 \\
\hline Rolando area & Motor cortex & 4 \\
\hline Rolando cells & Nerve cells in Rolando gelatinous substance of spinal cord & 11 \\
\hline Rolando column & $\begin{array}{l}\text { Slight ridge on either side of medulla oblongata related to the descending trigeminal tract } \\
\text { and nucleus }\end{array}$ & 11 \\
\hline Rolando fissure/sulcus & Central sulcus of telencephalon & 12 \\
\hline Rolando substance & $\begin{array}{l}\text { Gelatinous substance: the apical part of the posterior horn (dorsal horn; posterior gray } \\
\text { column) of the spinal cord's gray matter, composed largely of very small nerve cells; its } \\
\text { gelatinous appearance is due to its very low content of myelinated nerve fibres; spinal } \\
\text { lamina II }\end{array}$ & 11 \\
\hline Rolando tubercle & Trigeminal tubercle & 21 \\
\hline Roller nucleus & Perihypoglossal nucleus; Lateral nucleus of accessory nerve & 12 \\
\hline Rose nuclei & Intralaminar nuclei of thalamus & 20 \\
\hline Rosenmüller fossa & Pharyngeal recess & 12 \\
\hline Rosenmúller gland/node & Proximal nodes (belong to common iliac nodes) & 12 \\
\hline Rosenmúller organ & Epoophoron & 4 \\
\hline
\end{tabular}




\begin{tabular}{|c|c|c|}
\hline Rosenmúller plexus & Parotid plexus & 4 \\
\hline Rosenmüller valve & Lacrimal fold & 21 \\
\hline Rosenthal canal & Spiral canal of cochlea (modiolus) & 11 \\
\hline Rosenthal vein & Basal vein & 12 \\
\hline Roser-Nélaton line & Line drawn from the anterior superior iliac spine to the tuberosity of the ischium & 31 \\
\hline Rouget muscle & Circular/radial fibres of ciliary muscle & 12 \\
\hline Rouget-Neumann sheath & Uncalcified bone matrix between an osteocyte and the lacunar or canalicular wall & 11 \\
\hline Rouviere aponeurosis & Cenvico-pericardial fascia, clavipectoral fascia & 7 \\
\hline Russell uncinate bundle & Uncinate fasciculus of cerebellum & 12 \\
\hline Ruysch membrane & Capillary lamina of choroid & 11 \\
\hline Ruysch muscle & Muscular tissue of urinal fundus & 11 \\
\hline Ruysch tube & $\begin{array}{l}\text { Minute tubular cavity opening in the lower and anterior portion of each surface } \\
\text { of nasal septum }\end{array}$ & 11 \\
\hline Ruysch veins & Vorticose veins; retroperitoneal veins & 12 \\
\hline Sandström corpora & Parathyroid gland & 31 \\
\hline Santorini canal/duct & Accessory pancreatic duct & 12 \\
\hline Santorini cartilage & Corniculate cartilage & 12 \\
\hline Santorini caruncle minor/major & Minor/major duodenal papilla & 12 \\
\hline Santorini concha & Supreme nasal concha & 20 \\
\hline Santorini fissures/incisures/notch & Notch in cartilage of acoustic meatus & 11 \\
\hline Santorini labyrinth/plexus & Prostatic venous plexus & 11 \\
\hline Santorini muscle & $\begin{array}{l}\text { Procerus muscle; Risorius muscle; Muscle of terminal notch (related to the tragicus } \\
\text { muscle) }\end{array}$ & 12 \\
\hline Santorini tubercle & Corniculate tubercle & 21 \\
\hline Santorini vein & Parietal emissary vein & 11 \\
\hline Sappey veins & Para-umbilical veins & 12 \\
\hline Sattler layer & Vascular lamina of choroid & 12 \\
\hline Scarpa fascia & Membranous layer of subcutaneous tissue of abdomen & 12 \\
\hline Scarpa fluid/liquor & Endolymph & 11 \\
\hline Scarpa foramina & $\begin{array}{l}\text { Two openings in the line of intermaxillary suture; the anterior foramen } \\
\text { transmits the left nasopalatine nerve }\end{array}$ & 31 \\
\hline Scarpa ganglion & Vestibular ganglion & 12 \\
\hline Scarpa habenula & Cordlike remains of vaginal process of peritoneum & 11 \\
\hline Scarpa hiatus/orifice & Helicotrema & 11 \\
\hline Scarpa membrane & Secondary tympanic membrane & 11 \\
\hline Scarpa nerve & Nasopalatine nerve & 12 \\
\hline Scarpa sheath & Cremasteric fascia & 11 \\
\hline Scarpa sulcus & Vomeral groove & 11 \\
\hline Scarpa triangle & Femoral triangle & 12 \\
\hline Schlemm canal & Scleral venous sinus & 12 \\
\hline Schmidt-Lanterman incisures & $\begin{array}{l}\text { Funnel-shaped interruptions of major dense lines in the regular structure } \\
\text { of myelin sheath of nerve fibres }\end{array}$ & 31 \\
\hline Schneider membrane & Mucosa of nose & 11 \\
\hline Schüller duct & Paraurethral ducts & 11 \\
\hline Schultze comma tract & Interfascicular fasciculus & 12 \\
\hline Schultze comma tract/bungle & $\begin{array}{l}\text { Semilunar fasciculus: compact bundle composed of descending branches of posterior } \\
\text { root fibres located near the border between the fasciculi gracilis and cuneatus of the } \\
\text { cervical and thoracic spinal cord }\end{array}$ & 11 \\
\hline Schütz fasciculus, bundle & Posteriori/dorsal longitudinal fasciculus & 12 \\
\hline
\end{tabular}




\begin{tabular}{|c|c|c|}
\hline Schwalbe corpuscule & Taste bud & 21 \\
\hline Schwalbe nucleus & Magnocellular part of inferior vestibular nucleus & 12 \\
\hline Schwalbe ring & Anterior limiting lamina of cornea & 4 \\
\hline Schwalbe space & Episcleral space; Intervaginal subarachnoid space of optic nerve & 11 \\
\hline Schwann cell unit & $\begin{array}{l}\text { Single Schwann cell and those axons lying in troughs indenting its surface; this unit is } \\
\text { regarded as an unmyelinated fibre in the peripheral nervous system }\end{array}$ & 4 \\
\hline Sebileau hollow & Depression between the inferior aspect of tongue and the sublingual glands & 11 \\
\hline Sebileau muscle & Deep fibres of dartos tunic that pass into the scrotal septum & 31 \\
\hline Seiler cartilage & Small rod of cartilage attached to the vocal process of arytenoid cartilage & 20 \\
\hline Servetus circulation & Pulmonary circulation & 11 \\
\hline Shenton line & Curved line formed by the top of obturator foramen and the inner side of femoral neck & 20 \\
\hline Shin bone & Tibia & 31 \\
\hline Shrapnell membrane & Pars flaccid & 12 \\
\hline Sibson aponeurosis/fascia & Suprapleural membrane of endothoracic fascia & 12 \\
\hline Sibson groove & $\begin{array}{l}\text { Groove occasionally seen on the outer side of thorax formed by the prominent lower } \\
\text { border of pectoralis major muscle }\end{array}$ & 21 \\
\hline Sibson muscle & Scalenus minimus muscle & 12 \\
\hline Sibson vestibule & Aortic vestibule & 20 \\
\hline Skene tubules/duct & Paraurethral duct & 11 \\
\hline Skene glands & Urethral glands of female & 31 \\
\hline Soemmering foramen & Central fovea retinae & 11 \\
\hline Soemmering muscle & Levator glandulae thyroidae muscle & 11 \\
\hline Soemmering nerve & Pudendal nerve & 20 \\
\hline Soemmering substance & Substantia nigra & 12 \\
\hline Sondermann canal & $\begin{array}{l}\text { Blind outpouching of Schlemm canal, extending toward, but not communicating with, } \\
\text { the anterior chamber of eye }\end{array}$ & 11 \\
\hline Sorgius nodes & Pectoral axillary nodes & 17 \\
\hline Spence tail & Axillary process/tail of mammary gland & 12 \\
\hline Spiegel (Spieghel/Spigelius) line & Semilunar line of liver & 12 \\
\hline Spiegelian lobe & Caudate lobe & 12 \\
\hline Spigelian fascia & Aponeurotic layer between rectus abdominis and semilunar line & 1 \\
\hline Spitzka tract/zone & Posterolateral tract; Dorsolateral tract & 3 \\
\hline Staderini nucleus & Subhypoglossal nucleus & 12 \\
\hline Stenon duct & Parotid duct & 12 \\
\hline Stensen duct & Parotid duct & 31 \\
\hline Stenson canal & Incisive canal/suture & 7 \\
\hline Stenson foramen & Incisive foramina & 12 \\
\hline Stieda process & Posterior process of talus & 11 \\
\hline Stilling canal & Hyaloid canal & 12 \\
\hline Stilling column/nucleus & Posterior thoracic nucleus & 11 \\
\hline Stilling decussatio & Decussation of superior cerebellar peduncles & 20 \\
\hline Stilling gelatinous substance & $\begin{array}{l}\text { Central and lateral intermediate substances: the central gray matter of spinal cord } \\
\text { surrounding the central canal }\end{array}$ & 20 \\
\hline Stilling raphe & $\begin{array}{l}\text { Transverse interdigitations of fibre bundles across the anterior median fissure of medulla } \\
\text { oblongata at the decussation of pyramidal tracts }\end{array}$ & 20 \\
\hline Stilling-Clarke column nucleus & Posteriori/dorsal thoracic nucleus & 12 \\
\hline Stirling trigonum & Hypoglossal trigone & 7 \\
\hline Stroud pecten & Anal pecten & 12 \\
\hline Suzanne gland & Small mucous gland in the floor of oral cavity & 20 \\
\hline
\end{tabular}




\begin{tabular}{|c|c|c|}
\hline Sydney crease/line & Variation of proximal transverse palmar flexion crease that reaches the ulnar side of palm & 11 \\
\hline Sylvian angle & $\begin{array}{l}\text { Angle formed by the Sylvian line and a line perpendicular to the horizontal plane } \\
\text { tangential to the highest point of hemisphere }\end{array}$ & 11 \\
\hline Sylvian aqueduct & Cerebral aqueduct & 4 \\
\hline Sylvian cisterna & Subarachnoid space associated with the lateral cerebral sulcus & 11 \\
\hline Sylvian fissure & Lateral sulcus of telencephalon & 12 \\
\hline Sylvian line & Line of posterior limb of lateral sulcus & 11 \\
\hline Sylvian point & $\begin{array}{l}\text { Nearest point on the skull to the lateral (Sylvian) fissure, about } 30 \mathrm{~mm} \text { behind the } \\
\text { zygomatic process of the frontal bone }\end{array}$ & 11 \\
\hline Sylvian valve & Valve of inferior vena cava & 11 \\
\hline Sylvian ventricle & Cavity of septum pellucidum & 11 \\
\hline Symington anococcygeal body & Anococcygeal body/raphe & 11 \\
\hline Tarin fascia & Dentate gyrus in limbic lobe of brain & 1 \\
\hline Tarin space & Interpeduncular cistern & 7 \\
\hline Tarin tenia & Terminal stria & 4 \\
\hline Tarin valve/velum & Inferior medullary velum & 11 \\
\hline Tawara node & Atrioventricular node & 12 \\
\hline Tenon capsule/fascia & Fascial sheath of eyeball & 12 \\
\hline Tenon space & Episcleral space & 31 \\
\hline Terson glands & Conjunctival glands & 31 \\
\hline Testut artery & Inferior pancreatic artery & 12 \\
\hline Thabesian (Tebesio) foramina & Openings of smallest cardiac veins & 20 \\
\hline Thebesian (Tebesio) valve & Valve of coronary sinus & 12 \\
\hline Thebesian (Tebesio) veins & Small cardiac veins & 12 \\
\hline Theile canal & Transverse pericardial sinus & 11 \\
\hline Theile glands & Glands of biliary mucosa & 11 \\
\hline Theile muscle & Superficial transverse perineal muscle & 21 \\
\hline Thoma ampulla & Dilation of arterial capillary beyond the sheathed artery of spleen & 11 \\
\hline Thomason fascia & $\begin{array}{l}\text { 1. Inferior fibres of fascia of external oblique muscle attached to the posterior } \\
\text { surface of the inguinal ligament } \\
\text { 2. Thickened inferior margin of transversalis fascia }\end{array}$ & \\
\hline Thompson fascia/bandaletta & Suprapubic tract & 11 \\
\hline Thompson ligament & lliopubic tract & 11 \\
\hline Thomson fascia & lliopectineal fascia and septum & 11 \\
\hline Tiedemann gland & Greater vestibular gland & 20 \\
\hline Tiedemann nerve & Sympathetic nerve accompanying the central artery of retina in the optic nerve & 12 \\
\hline Toldt fascia & Fascia behind body of pancreas & 1 \\
\hline Toldt white line & $\begin{array}{l}\text { Lateral reflection of posterior parietal pleura of abdomen over the mesentery of the } \\
\text { ascending and descending colon; Junction of parietal peritoneum with rectoprostatic fascia }\end{array}$ & 11 \\
\hline Tomes granular layer & Thin layer of dentin adjacent to the cementum, appearing granular in ground sections & 20 \\
\hline Torin hole & Hiatus for greater petrosal nerve & 12 \\
\hline Tourtual membrane & Quadrangular membrane & 11 \\
\hline Tourtual sinus & Supratonsillar fossa & 11 \\
\hline Toynbee muscle & Tensor tympani muscle & 11 \\
\hline Traube space & $\begin{array}{l}\text { Crescentic space about 12-cm wide, bounded medially by the left border of sternum, } \\
\text { above by an oblique line from the sixth costal cartilage to the lower border of eighth or } \\
\text { ninth rib in the midaxillary line and below by the costal margin }\end{array}$ & 4 \\
\hline Treitz arch & Paraduodenal fold & 11 \\
\hline Treitz fascia & Fascia behind the head of pancreas & 1 \\
\hline
\end{tabular}




\begin{tabular}{|c|c|c|}
\hline Treitz fossa & Subcaecal fossa & 11 \\
\hline Treves fold/bloodless fold & lleocaecal fold & 11 \\
\hline Treitz ligament & Suspensory ligament of duodenum & 12 \\
\hline Treitz muscle & Suspensory muscle of duodenum & 31 \\
\hline Trolard plexus & Venosus plexus of hypoglossal canal & 11 \\
\hline Trolard vein & $\begin{array}{l}\text { Superior anastomotic vein: a large communicating vein between the superficial middle } \\
\text { cerebral vein and the superior sagittal sinus }\end{array}$ & 12 \\
\hline Tröltsch corpuscles & $\begin{array}{l}\text { Minute spaces, resembling corpuscles, between the radial fibres of drum } \\
\text { membrane of ear }\end{array}$ & 20 \\
\hline Tröltsch fold & Posterior mallear fold & 21 \\
\hline Tröltsch pockets/recesses & Anterior and posterior recess of tympanic membrane & 11 \\
\hline Tsai tegmental area & Subbrachial nucleus & 12 \\
\hline Tulp valve & $\begin{array}{l}\text { Valve seen in the cadaver as a bilabial prominence of terminal ileum protruding into } \\
\text { the large intestine at the caecocolic junction (valva); in a living person, it appears as } \\
\text { a truncated cone with a star-shaped orifice }\end{array}$ & 31 \\
\hline Türck bundle & Temporopontine fibres & 12 \\
\hline Türck column & Anterior corticospinal tract; Ventral corticospinal tract & 12 \\
\hline Turkish saddle & Sella turcica & 4 \\
\hline Turner sulcus & Intraparietal sulcus & 11 \\
\hline Tyrrell fascia & Rectovesical septum & 12 \\
\hline Tyson glands & Preputial glands & 31 \\
\hline Valentin ganglion & Ganglion on the superior alveolar nerve & 21 \\
\hline Valentin nerve & Nerve that connects the pterygopalatine ganglion with the abducens nerve & 11 \\
\hline Valpeau fossa & Ischioanal fossa & 20 \\
\hline Valsalva antrum/cavity & Mastoid antrum/cavity & 20 \\
\hline Valsalva ligaments & Ligaments of auricle & 20 \\
\hline Valsalva muscle & Tragicus muscle & 11 \\
\hline Valsalva nodules & Nodules of semilunar cusps & 12 \\
\hline Valsalva sinus & Aortic sinus & 12 \\
\hline Van Horne duct & Thoracic duct & 11 \\
\hline Varolius muscle & Stapedius muscle & 31 \\
\hline Varolius pons & Pons & 12 \\
\hline Varolius sphincter & lleal sphincter & 4 \\
\hline Varolius valve & lleocaecal valva; lleal orifice & 11 \\
\hline Vater ampulla & Hepatopancreatic ampulla & 12 \\
\hline Vater corpuscles & $\begin{array}{l}\text { Lamellated corpuscles: small oval bodies in the skin of fingers, in the mesentery, tendons, } \\
\text { and elsewhere, formed of concentric layers of connective tissue with a soft core in which } \\
\text { the axon of a nerve fibre runs, splitting up into a number of fibrils that terminate in } \\
\text { bulbous enlargements; they are sensitive to pressure }\end{array}$ & 11 \\
\hline Vater fold & Fold of mucous membrane in the duodenum just above the greater duodenal papilla & 8 \\
\hline Vater papilla/tubercle & Major duodenal papilla & 12 \\
\hline Velpeau canal & Inguinal canal & 11 \\
\hline Velpeau fascia & Transversalis fascia & 1 \\
\hline Vesalius bone & Tuberosity of fifth metatarsal bone & 20 \\
\hline Vesalius foramen & Sphenoidal emissary foramen & 12 \\
\hline Vesalius ligament & Inguinal ligament; Fundiform ligament of clitoris & 12 \\
\hline Vesalius vein & Emissary vein passing through the foramen venosum & 20 \\
\hline Vesling line & Raphe of scrotum & 11 \\
\hline Vicq dAzyr bundle & Mammillothalamic fasciculus & 12 \\
\hline
\end{tabular}




\begin{tabular}{|c|c|c|}
\hline Vicq dAzyr centrum & Centrum semiovale & 11 \\
\hline Vicq dAzyr foramen & Foramen caecum of medulla oblongata & 12 \\
\hline Vicq dAzyr stria & Occipital stripe of stria of internal granular layer of isocortex & 12 \\
\hline Vidian artery & Artery of pterygoid canal & 12 \\
\hline Vidian canal & Pterygoid canal & 12 \\
\hline Vidian nerve & Nerve of pterygoid canal & 12 \\
\hline Vidian veins & Vein of pterygoid canal & 12 \\
\hline Vieussen ansa/loop & Subclavian ansa & 11 \\
\hline Vieussen anulus/border/isthmus/limbus/ring & Border of cardiac oval fossa & 12 \\
\hline Vieussen centrum & Centrum semiovale of telencephalon & 11 \\
\hline Vieussen foramina & Openings of smallest cardiac veins & 11 \\
\hline Vieussen ganglia & Celiac ganglia & 11 \\
\hline Vieussen valve/velum & Superior medullary velum & 11 \\
\hline Vieussen veins & Innominate cardiac veins & 11 \\
\hline Vieussen ventricle & Cavity of septum pellucidum & 11 \\
\hline Virchow angle & $\begin{array}{l}\text { Angle formed by the meeting of a line drawn from the middle of nasofrontal suture to the } \\
\text { base of the anterior nasal spine with a line drawn from this last point to the centre of the } \\
\text { external auditory meatus }\end{array}$ & 11 \\
\hline Virchow-Robin space & $\begin{array}{l}\text { Tunnel-like extension of subarachnoid space surrounding blood vessels that pass into the } \\
\text { brain or spinal cord from the subarachnoid space }\end{array}$ & 4 \\
\hline Volkmann canals & Vascular canals in compact bone & 4 \\
\hline von Gudden commissure & Ventral supra-optic commissure & 12 \\
\hline von Gudden ganglion & Dorsal subdivision of nucleus of posterior commissure of midbrain & 12 \\
\hline von Gudden nucleus & Posterior/dorsal tegmental nucleus & 12 \\
\hline von Gudden tract & Mammillotegmental fasciculus & 12 \\
\hline Vossius lenticular ring & $\begin{array}{l}\text { Annular opacity found on the anterior lens capsule after contusion of eye, due to pigment } \\
\text { and blood }\end{array}$ & 11 \\
\hline Wachendorf membrane & Pupillary membrane: remnants of central portion of the anterior layer of the iris stroma & 20 \\
\hline Waldeyer fascia & Inferior fascia of pelvic diaphragm & 12 \\
\hline Waldeyer fosse & $\begin{array}{l}\text { Inferior and superior duodenal fossae: peritoneal recess which lies behind the } \\
\text { inferior/superior duodenal fold and along the ascending part of the duodenum }\end{array}$ & 7 \\
\hline Waldeyer glands & Coil glands near the margins of eyelids & 11 \\
\hline Waldeyer organ & Paradydymis & 12 \\
\hline Waldeyer ring & Pharyngeal lymphoid ring & 12 \\
\hline Waldeyer sheath/space & Tubular space between the bladder wall and the intramural portion of ureter & 11 \\
\hline Waldeyer tract/zonal layer & Dorsolateral fasciculus & 11 \\
\hline Walther duct & Minor sublingual ducts & 11 \\
\hline Walther ganglion & Coccygeal ganglion; Ganglion impar & 11 \\
\hline Walther ligament & Anterior tibiofibular ligament & 11 \\
\hline Walther plexus & Cavernous nerve plexus & 11 \\
\hline Weber glands & Muciparous glands at the border of tongue on either side, posteriorly & 4 \\
\hline Weber organ & Prostatic utricle & 20 \\
\hline Weber tringle & $\begin{array}{l}\text { Area indicated by the heads of first and fifth metatarsal bones and the centre of plantar } \\
\text { surface of heel on the sole of the foot }\end{array}$ & 20 \\
\hline Weisbach angle & $\begin{array}{l}\text { Craniometric angle formed by the junction, at the alveolar point, of lines passing from the } \\
\text { basion and from the middle of the frontonasal suture }\end{array}$ & 11 \\
\hline Weitbrecht apparatus ligamentosus & Tectorial membrane of median atlantoaxial joint & 11 \\
\hline Weitbrecht cartilage & Articular disc of acromioclavicular joint & 11 \\
\hline Weitbrecht cord/ligament & Oblique cord of interosseous membrane of forearm & 11 \\
\hline
\end{tabular}




\begin{tabular}{|c|c|c|}
\hline Weitbrecht decussatio & Decussation of superior cerebellar peduncles & 11 \\
\hline Weitbrecht fibres & Retinaculum of articular capsule of hip joint & 11 \\
\hline Weitbrecht foramen & $\begin{array}{l}\text { Opening in the articular capsule of shoulder joint, communicating with the subtendinous } \\
\text { bursa of the subscapularis muscle }\end{array}$ & 11 \\
\hline Welcker angle & Sphenoidal angle of parietal bone & 11 \\
\hline Welfring glands & Accessory lacrimal glands & 31 \\
\hline Wenzel ventricle & Cavity of septum pellucidum & 11 \\
\hline Wepfer glands & Duodenal glands & 11 \\
\hline Wernekink decussatio & Decussation of superior cerebellar peduncles & 12 \\
\hline Wernicke area/centre/field/region/zone & $\begin{array}{l}\text { Region of cerebral cortex thought to be essential for understanding and formulating } \\
\text { coherent, propositional speech (Brodmann areas 40,39, and adjacent portions of 22) }\end{array}$ & 11 \\
\hline Wernicke radiation & Optic radiation & 4 \\
\hline Westberg space & Space surrounding the origin of aorta, which is invested with the pericardium & 20 \\
\hline Westphal-Edinger nucleus & Visceral/autonomic nucleus of oculomotor nerve & 31 \\
\hline Wharton duct & Submandibular duct & 12 \\
\hline Wharton jelly & Mucoid (mucous-like) connective tissue of umbilical cord & 31 \\
\hline Whitnall tubercle & Marginal tubercle of zygomatic bone & 12 \\
\hline Wilkie artery & Supraduodenal artery & 12 \\
\hline Willis centrum nervosum & Celiac ganglia & 11 \\
\hline Willis circle & Cerebral arterial circle & 12 \\
\hline Willis cords & Fibrous cords crossing the superior sagittal sinus & 11 \\
\hline Willis nerve & Accessory nerve & 12 \\
\hline Willis pancreas & Uncinate process of pancreas & 11 \\
\hline Wilson muscle & External urethral sphincter & 21 \\
\hline Winslow foramen & Omental/epiploic foramen & 12 \\
\hline Winslow ligament & Oblique popliteal ligament; Fibular collateral ligament & 12 \\
\hline Winslow pancreas & Uncinate process of pancreas & 12 \\
\hline Winslow stars & Capillary whorls in the lamina choroidocapillaris from which arise the vorticosae venae & 11 \\
\hline Wirsung duct & Sphincter of pancreatic duct & 12 \\
\hline Wolffian body/organ & Mesonephros & 11 \\
\hline Wolffian duct & Mesonephric duct & 11 \\
\hline Wolffian ridge & Urogenital ridge & 11 \\
\hline Wolffian tubules & Mesonephros & 31 \\
\hline Wolfring glands & Accessory lacrimal glands & 12 \\
\hline Wood muscle & Abductor muscle of fifth metatarsal & 12 \\
\hline Wormian bone & $\begin{array}{l}\text { Sutural bone: small irregular bones found along the sutures of the cranium, particularly } \\
\text { related to the parietal bone }\end{array}$ & 12 \\
\hline Wrisberg cartilage/tubercle & Cuneiform cartilage & 12 \\
\hline Wrisberg ganglion & Cardiac ganglia & 12 \\
\hline Wrisberg ligament & Posterior meniscofemoral ligament & 12 \\
\hline Wrisberg nerve & Intermediate nerve, Medial cutaneous nerve of arm, Medial brachial cutaneous nerve & 12 \\
\hline Zaglas ligament & $\begin{array}{l}\text { Fibrous band extending from the posterior superior spine of ileum to the second } \\
\text { transverse tubercle of sacrum }\end{array}$ & 11 \\
\hline Zeis glands & Sebaceous glands opening into the follicles of eyelashes & 12 \\
\hline Zinn annulus /ligament/ring/tendon & Common tendinous ring, Common annular tendon of extra-ocular muscle & 12 \\
\hline Zinn artery & Central retinal artery & 12 \\
\hline Zinn circulus/circle/corona & Vascular circle of optic nerve & 11 \\
\hline Zinn membrane & Anterior layer of iris & 11 \\
\hline
\end{tabular}




\begin{tabular}{llc}
\hline Zinn zonule & Ciliary zonule & 12 \\
\hline Zuckerkandl bodies & Para-aortic bodies; Aortic glomera & 12 \\
\hline Zuckerkandl convolution/gyrus & Subcallosal gyrus & 24 \\
\hline Zuckerkandl fascia & Posterior layer of renal fascia & 12 \\
\hline Zuckerkandl gland & Thyroid gland & 4 \\
\hline
\end{tabular}

\section{REFERENCES}

1. Adstrum S (2015) Fascial eponyms may help elucidate terminological and nomenclatural development. J Bodyw Mov Ther, 19: v516-v525.

2. al-al-Qattan MM (1996) Gantzer's muscle. An anatomical study of the accessory head of the flexor pollicis longus muscle J Hand Surg Br, 21: 269-270.

3. Bartolucci S, Forbis P (2004) Stedman's medical eponyms book. Lippincott Williams \& Wilkins, Baltimore.

4. Bochenek A, Reicher M (2010) Anatomia Człowieka. PZWL, Warszawa.

5. Boonstra EA, Lorenz K, Porte RJ (2014) The quest for Luschka's duct: an eponym leading a life of its own? Dig Surg, 31: 104-107.

6. Cohen MM Jr (2010) Genetic drift. Overview of German, Nazi, and Holocaust medicine. Am J Med Genet A, 152A: 687-707.

7. Encyclopedia Britannica (2015) Available at http://www. britannica.com (last access Dec 01, 2015).

8. Enersen OD (2015) Available at http://www.whonamedit. com (last access Dec 01, 2015).

9. Evans WN (2008) Tetralogy of Fallot and Etienne-Louis Arthur Fallot. Pediatr Cardiol, 29: 637-640.

10. Fargen KM, Hoh BL (2014) The debate over eponyms. Clin Anat, 27: 1137-1140.

11. Farlex Inc. (2015) Available at http://medical-dictionary. thefreedictionary.com (last access Dec 01, 2015).

12. Federative Committee on Anatomical Terminology - FCAT (1998) Terminologia Anatomica — International anatomical terminology. Thieme, Stuttgart.

13. Fischer JE, Bland KI, Callery MP, ClagettGP, Jones DB, LoGerfo FW, Seeger JM (2007) Mastery of surgery. Lippincott Williams \& Wilkins, Philadelphia.

14. Georgopoulos DS (2004) In pursuit of an eponym. Tex Heart Inst J, 31: 335.

15. Gobée OP, Jansma D, DeRuiter MC (2011) AnatomicalTerms. info: heading for an online solution to the anatomical synonym problem hurdles in data-reuse from the Terminologia Anatomica and the foundational model of anatomy and potentials for future development. Clin Anat, 24: 817-830.
16. Hirsch Martin C (2013) Glossar der Neuroanatomie Taschenbuch. Springer-Verlag, Berlin.

17. Kern KA (1999) Sentinel lymph node mapping in breast cancer using subareolar injection of blue dye. J Am Coll Surg, 189: 539-545.

18. Kostovic I (2003) Guidance cues in the developing brain. Springer-Verlag. Berlin.

19. Lo WB, Ellis H (2010) The circle before Willis: a historical account of the intracranial anastomosis. Neurosurgery, 66: 7-18.

20. MediLexicon International Ltd. (2015) Available at http:// www.medilexicon.com (last access Dec 01, 2015).

21. Mondofacto Fabrium Center (2015) Available at http:// www.mondofacto.com (last access Dec 01, 2015).

22. Olry R (2014) Anatomical eponyms, part 1: to look on the bright side. Clin Anat, 27: 1142-1144.

23. Olry R (2014) Anatomical eponyms, part 2: The other side of the coin. Clin Anat, 27: 1145-1148.

24. SpellChecker (2015) Available at https://www.spellchecker. ne (last access Dec 01, 2015).

25. Strous RD, Edelman MC (2007) Eponyms and the Nazi era: time to remember and time for change. Isr Med Assoc J, 9: 207-314.

26. Swanson LW (2014) Neuroanatomical Terminology: A Lexicon of classical origins and historical foundations. Oxford University Press, New York.

27. Van Praagh R. Etienne-Louis (1989) Arthur Fallot and his tetralogy: a new translation of Fallot's summary and a modern reassessment of this anomaly. Eur J Cardiothorac Surg, 3: 381-386.

28. Vilensky JA (2014) The neglected cranial nerve: Nervus Terminalis (Cranial Nerve N). Clin Anat, 27: 46-53.

29. Werneck AL, Batigália $F$ (2011) Anatomical eponyms in cardiology from to the 60 s to the XXI century. Rev Bras Cir Cardiovasc, 26: 98-106.

30. Whitworth JA (2007) Should eponyms be abandoned? No. BMJ, 335: 425.

31. Wikipedia (2015) Available at https://en.wikipedia.org (last access Dec 01, 2015).

32. Woywodt A, Matteson E (2007) Should eponyms be abandoned? Yes. BMJ, 335: 424 